Article

\title{
Reconstruction of Atmospheric Lead Pollution During the Roman Period Recorded in Belgian Ombrotrophic Peatlands Cores
}

\author{
Mohammed Allan 1,*, Daniele L. Pinti ${ }^{2}$ (D), Bassam Ghaleb ${ }^{2}$, Sophie Verheyden ${ }^{3}$, \\ Nadine Mattielli ${ }^{4}$ and Nathalie Fagel ${ }^{1}$ \\ 1 UR Argiles, Géochimie et Environnements sédimentaires (AGEs), Département de Géologie, \\ Université de Liège, 4000 Liège, Belgique; nathalie.fagel@uliege.be \\ 2 GEOTOP Research Center for the Dynamics of the Earth System, Université du Québec à Montréal, \\ Succ. Centre-Ville CP 8888, Montreal, QC H3C 3P8, Canada; pinti.daniele@uqam.ca (D.L.P.); \\ ghaleb.bassam@uqam.ca (B.G.) \\ 3 Royal Belgian Institute of Natural Sciences (RBINS), Earth and History of Life, Rue Vautier 29, \\ 1000 Brussels, Belgium; veso@belspo.be \\ 4 G-Time, Université Libre de Bruxelles, Avenue Franklin Roosevelt, 1050 Brussels, Belgium; \\ nmattiel@ulb.ac.be \\ * Correspondence: mohammedallan@outlook.com; Tel.: +32-4-366-98-71; Fax: +32-4-366-20-29
}

Received: 14 May 2018; Accepted: 2 July 2018; Published: 5 July 2018

\begin{abstract}
Two peat cores from two bogs were used to record changes in the atmospheric $\mathrm{Pb}$ accumulation rate $(\mathrm{Pb} \mathrm{AR})$ in Belgium during the Roman period. The two records were compared to assess the reliability of peat cores as archives of atmospheric $\mathrm{Pb}$ deposition and to establish histories of atmospheric emissions from anthropogenic sources. To address these issues we analyzed $\mathrm{Pb}$ concentration and its isotopes, using ICP-MS, LA-ICP-MS and MC-ICP-MS in two peat sections, spanning 1000 years each. Lead concentrations in the two cores range from 0.1 to $60 \mu \mathrm{g} \mathrm{g}^{-1}$, with the maxima between 15 and $60 \mu \mathrm{g} \mathrm{g}^{-1}$. The average natural background of $\mathrm{Pb}$ AR varies between 0.003 and $0.07 \mathrm{mg} \mathrm{m}^{-2} \mathrm{yr}^{-1}$ and the maximum ranges from 0.7 to $1.2 \mathrm{mg} \mathrm{m}^{-2} \mathrm{yr}^{-1}$ between $50 \mathrm{BC}$ and $\mathrm{AD} 215$. The highest $\mathrm{Pb}$ AR exceed the pre-Roman period values by a factor of $17-80$. Pb isotopic composition indicates that mining and metallurgical activities were the predominant sources of pollution during the Roman period. The $\mathrm{Pb} \mathrm{AR}$ and chronologies in the Belgian peat cores are consistent with those reported for other continental archives such as lake sediments, peat and ice cores.
\end{abstract}

Keywords: atmospheric pollution; $\mathrm{Pb}$ accumulation rate; peat geochemistry; Roman period; $\mathrm{Pb}$ isotopes

\section{Introduction}

Lead $(\mathrm{Pb})$ is one of the most investigated metals in the environment because of its high potential toxicity [1-4]. Lead anthropogenic fluxes are derived from human activities such as mining, industry, coal burning and the use of leaded gasoline [5-7]. To assess the extent of atmospheric lead contamination, it is necessary to identify the main anthropogenic and natural sources. Lead has four stable isotopes $\left({ }^{204} \mathrm{~Pb},{ }^{206} \mathrm{~Pb},{ }^{207} \mathrm{~Pb}\right.$ and $\left.{ }^{208} \mathrm{~Pb}\right)$. The last three isotopes are the end-products of the natural decay chains of uranium and thorium. The isotopic composition of lead ores is usually different from that of bedrock [8]. Consequently, lead isotopes enable us to discriminate between $\mathrm{Pb}$ sources of pollutants and $\mathrm{Pb}$ derived from the erosion of the Earth crust. Lead isotopes ratios $\left({ }^{206} \mathrm{~Pb} /{ }^{207} \mathrm{~Pb}\right.$ and 
${ }^{208} \mathrm{~Pb} /{ }^{207} \mathrm{~Pb}$ ) have been often used as evidence of anthropogenic heavy metal pollution, particularly in peatlands $[2,5,9-13]$.

The magnitude and timing of changes in atmospheric $\mathrm{Pb}$ pollution have been studied in a variety of environmental archives (e.g., lake and marine sediments, ice cores and peat) [1,2,5,14-16]. In the recent study of a peat core from La Molina mire (N Spain), Martinez Cortizas et al. [17] showed that the earliest atmospheric $\mathrm{Pb}$ pollution in SW Europe dates back to 5000 years ago. Later, during the Roman period (100 BC-AD 400) production of silver and lead was widespread [18] and fall-out of atmospheric emissions caused an increase of $\mathrm{Pb}$ atmospheric pollution which was recorded in peat and lake sediments in Europe and in the Greenland ice cores $[1,5,14,17]$. The Roman period showed an increase in world lead production, up to 80,000 tons/year, which was about the same magnitude than that of the Industrial Revolution (from AD 1850 to the present) [14,18]. Approximately 5\% of the 80,000 tons lead production went into the atmosphere [14]. Roman civilization is well known for its large-scale impact on the landscapes and environments of Europe, northern Africa, and the Middle East. Lead emissions coming from mining and metallurgical activities caused an important local and regional air pollution throughout Europe $[4,5,19,20]$. The most important lead mines were situated in SW Europe (Iberia) and in SE Europe [21]. About $40 \%$ of the lead production came from Spain, center Europe, Britain, Greece and Minor Asia [21]. Then, $\mathrm{Pb}$ production suddenly decreased after the fall of the Roman civilization and reached its minimum in the Middle Age. In the Roman period, ${ }^{206} \mathrm{~Pb} /{ }^{207} \mathrm{~Pb}$ ratio values of anthropogenic sources ranged between 1.177 and 1.185 [22].

Ombrotrophic peatlands can provide valuable information about the atmospheric inputs of trace metals [2,23-26] because they are fed with nutrients and pollutants only through atmospheric inputs. Most important, peat is particularly effective at preserving lead atmospheric deposition [5,27-30]. However, due to numerous factors influencing peat elemental composition, the behavior of metal elements is not always well understood despite the numerous studies carried out. The crucial factor is post-depositional migration of metals. The metal elements mobility may be due to various factors such as adsorption on oxy-hydroxides, water table fluctuation, variations in $\mathrm{pH}$ [31,32], or uptake and recycling by plants $[33,34]$. Among all metals, $\mathrm{Pb}$ has been most often targeted for recording its atmospheric deposition history [35]. Numerous studies demonstrated that $\mathrm{Pb}$ is an immobile element in ombrotrophic bogs based on stable and radioactive $\mathrm{Pb}$ isotopes, $\mathrm{Pb}$ profiles in porewaters comparison with rain collectors and herbarium samples and transplant experiments [35-38]. However, some investigations also demonstrated that $\mathrm{Pb}$ can be affected by diagenetic remobilization and redistribution processes in saturated peats [39].

Belgium, as a part of Gallia Belgica (northern France, western Germany, southern Netherlands and Belgium, Figure 1A), was occupied by the Roman Empire from 50 BC to AD 350. The Hautes Fagnes Plateau (SE Belgium) has provided a key site in studies investigating human occupation and environmental impact in the region since the Celtic occupation [40-44]. This area is also situated south of $\mathrm{Pb}-\mathrm{Zn}$ ore deposits (extracted since Roman period [44,45]) and nearby the German border which is $300 \mathrm{~km}$ from the Region of the Ruhr-Eifel industrial area. At the site, several archaeological $[40,44,46,47]$ and historical [42] investigations support Roman occupation and ore mining. Previous studies, at lower resolution, in ombrotrophic bogs from the Hautes Fagnes plateau [43,48-51] and peaty sediments [52] showed that the atmospheric pollution in Belgium dated back to early Roman times. For example, De Vleeschouwer et al [43], by using an ombrotrophic peat core from Misten, demonstrated an increase in $\mathrm{Pb}$ concentrations in samples dating to the Roman period. This was interpreted as a result of increase in $\mathrm{Pb}-\mathrm{Zn}$ ores mining and agricultures activities. In this work, high-resolution $\mathrm{Pb}$ concentrations and stable $\mathrm{Pb}$ isotopic compositions in two ombrotrophic peatlands from Hautes Fagnes Plateau (SE Belgium) are used: (1) to track the history of $\mathrm{Pb}$ pollution in Belgium during the Roman period; (2) to identify the local and regional $\mathrm{Pb}$ sources and; (3) to reconstruct the historical evolution of $\mathrm{Pb}$ pollution in comparison with other European archives. 


\section{Materials and Methods}

\subsection{Sampling and Preparation}

The present study is focused on the sections covering the Roman period of two ombrotrophic peatlands located in a nationally protected peatland area, the Hautes-Fagnes Plateau in Eastern Belgium (Figure 1B-D). The Hautes-Fagnes Plateau is part of the Stavelot Massif, mainly composed of Lower Paleozoic quartzites and phyllites [53]. The geological substratum is covered by post-Paleozoic sediments (clays of alteration, continental and marine sands, loess [54]) with some occasional outcrops of Early Cambrian (Revinian) quartzites. Core MIS-08-01b $(750 \mathrm{~cm}$ ) was taken in February 2008 from the Misten bog that is made of an accumulation of $8 \mathrm{~m}$ (estimated by a radar surface prospecting [55]) of Holocene peat [43]. Core (CLE-15-01b, $550 \mathrm{~cm}$ ) was taken in July 2015, from Clefaye bog, which the maximum peat thickness reaches $5.5 \mathrm{~m} \mathrm{[55]} \mathrm{and} \mathrm{the} \mathrm{complete} \mathrm{peat} \mathrm{deposit} \mathrm{section} \mathrm{spans} \mathrm{about}$ 7000 years. The two ombrotrophic peatlands studied lie just $8 \mathrm{~km}$ apart.

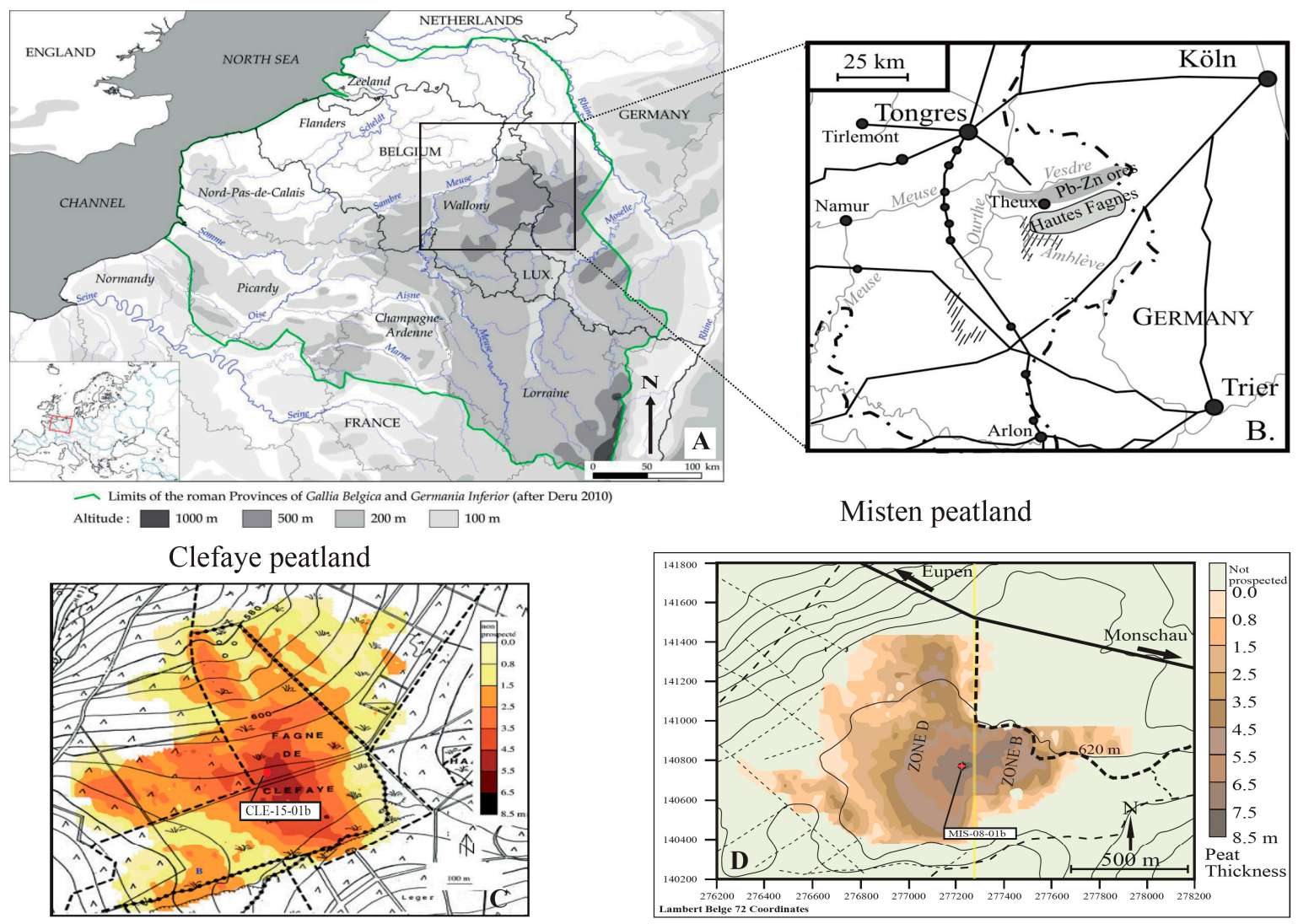

Figure 1. (A) Localisation of Belgium as a part of Gallia Belgica (northern France, western Germany, southern Netherlands and Belgium) (after Deru [56]), (B) Location map of the Hautes Fagnes Plateau and the Pb-Zn ores of E-Belgium (modified from De Vleeschouwer et al. [43]), (C,D) Radar derived peat thickness of the Clefaye and Misten bogs (modified after Wastiaux and Schumacker [55]). Coring location is reported by the red circle.

The top $100 \mathrm{~cm}$ of the two cores was sampled by using a titanium Wardenaar corer. The lower peat core was cored with a Belorussian corer [57]. Since we mainly focus our study on the Roman period, $60 \mathrm{~cm}$ from Clefaye bog (from 165 to $225 \mathrm{~cm}$ ) and $90 \mathrm{~cm}$ from Misten bog (from 90 to 180) which represents 1000 yrs history (from $500 \mathrm{BC}$ to AD 500) were used. Core sub-samples of 1 -cm-thick slices were taken according to the protocol defined by Givelet et al. [58]. In Clefaye bog, the sample slices were sub-sampled into three. The first part was used for geochemical analysis and the remaining core samples were stored for further analyses, including dating used in another study. 


\subsection{Data from Previous Research}

The ${ }^{14} \mathrm{C}$ and ${ }^{210} \mathrm{~Pb}$ data and the age model for core Clefaye (CLE) are reported in Allan et al. [59], while the age model of Misten (MIS) is reported in Allan et al. [60]. The age-depth models show that the two cores exhibit very different growth rates, with an average value of $0.6 \mathrm{~mm} \mathrm{yr}^{-1}$ for CLE and $1 \mathrm{~mm} \mathrm{yr}^{-1}$ for MIS for the studied period (from $500 \mathrm{BC}$ to AD 500). Consequently, the analysis of $\mathrm{Pb}$, $\mathrm{Sc}, \mathrm{Ti}$, and $\mathrm{Al}$, in core CLE, each $0.1 \mathrm{~cm}$ interval corresponds to a sample of $0.5-1$ year. In core MIS, $2 \mathrm{~cm}$ interval corresponds to 20 years. For the core MIS, the $\mathrm{Pb}$ isotopic data for the Roman period are from Fagel et al. [61].

\subsection{Elemental Geochemistry and Pb Isotope Analyses}

The samples from each core were analyzed separately using different methods as they were initially part of two different studies.

\subsubsection{CLE-15-01b Core (CLE)}

The CLE samples were subsampled as 4-cm-long and 0.5 -cm-thick slices and were impregnated (De Vleeschouwer et al. [62], Boes and Fagel [63]) in order to consolidate them before analysis of scandium (Sc), Titanium (Ti), Aluminum $(\mathrm{Al})$ and Lead $(\mathrm{Pb})$ concentrations. The concentrations were determined by Laser Ablation Inductively Coupled Plasma-Mass Spectrometer (LA-ICP-MS) connected to an ESI New Wave UP-193FX Fast Excimer ArF laser of $193 \mathrm{~nm}$ at the Royal Museum for Central Africa (Tervuren, Belgium). Spots were made of 50- $\mu \mathrm{m}$ diameter (spaced at 1-mm intervals, samples $\mathrm{n}=595$ ). Detection limits were calculated from the intensity and standard deviation measurements of the blank. The limits of quantification were $0.01 \mu \mathrm{g} \mathrm{g}^{-1}$ for Sc and $\mathrm{Pb}, 1.5 \mu \mathrm{g} \mathrm{g}{ }^{-1}$ for $\mathrm{Al}$ and $0.1 \mu \mathrm{g} \mathrm{g}^{-1}$ for Ti. Four certified plant standards (NIMT, 1547, NJV941, and NJV942) were used to assess the external analytical reproducibility. Comparison between reference values and measured values were satisfactory within $\geq 80 \%$.

A second aliquot was used to measure the $\mathrm{Pb}$ isotopic composition (Table 1). Radiogenic isotope pretreatments were carried out in a class-100 clean laboratory at ULg. About $100 \mathrm{mg}$ of dried peat was placed $6 \mathrm{~h}$ into an oven at $550{ }^{\circ} \mathrm{C}$ to remove by combustion all organic matter. After calcination, the samples were dissolved in a mixture of concentrated $\mathrm{HNO}_{3}$ and $\mathrm{HF}$ in a proportion of 1:4 and heated at $125^{\circ} \mathrm{C}$ for $48 \mathrm{~h}$. The solution was evaporated to dryness and the residue was re-dissolved in $2 \mathrm{~mL}$ of $6 \mathrm{M} \mathrm{HCl}$ to ensure complete digestion and the solutions were evaporated. For separation of $\mathrm{Pb}$ isotopes, the samples were dissolved in $0.5 \mathrm{~mL}$ of $0.8 \mathrm{M} \mathrm{HBr}$ and passed on Teflon column filled with AG1-X8 resin. The Pb isotopic ratios were measured using an MC-ICP-MS (Multi Collector-Inductively Coupled plasma Mass Spectrometry, Nu plasma), at the Department of Earth and Environment Sciences, (ULB, Belgium). The mass fractionation was internally corrected for mass bias using the known ${ }^{205} \mathrm{Tl} /{ }^{203} \mathrm{Tl}$ ratio [64]. During the analysis, the Pb NBS981 standard was repeatedly measured in alternation with samples in order to control any daily instrument drift. The isotope ratios of the NBS981 standard were stable during the analysis session $\left(\mathrm{n}=47,{ }^{208} \mathrm{~Pb} /{ }^{204} \mathrm{~Pb}=36.7052 \pm 0.0094(2 \mathrm{~s})\right.$, $\left.{ }^{207} \mathrm{~Pb} /{ }^{204} \mathrm{~Pb}=15.4954 \pm 0.003(2 \mathrm{~s}),{ }^{206} \mathrm{~Pb} /{ }^{204} \mathrm{~Pb}=16.9394 \pm 0.0034(2 \mathrm{~s})\right)$. These values are consistent with the recommended values and are in agreement with the laboratory long-term values $\left({ }^{208} \mathrm{~Pb} /{ }^{204} \mathrm{~Pb}\right.$ $\left.36.709 \pm 0.021,{ }^{207} \mathrm{~Pb} /{ }^{204} \mathrm{~Pb} 15.4951 \pm 0.0066,{ }^{206} \mathrm{~Pb} /{ }^{204} \mathrm{~Pb} 16.9392 \pm 0.0006, \mathrm{n}=350\right)$. 
Table 1. Pb isotope data of the CLE and MIS cores measured MC-ICP-MS. * correspond to duplicate analyses.

\begin{tabular}{|c|c|c|c|c|c|c|c|c|c|c|c|}
\hline Core & Depth (cm) & $208 / 204$ & \pm 2 se & 207/204 & \pm 2 se & $206 / 204$ & \pm 2 se & 208/206 & \pm 2 se & 206/207 & \pm 2 se \\
\hline \multirow[t]{24}{*}{ CLE } & 38 & 38.0280 & 0.0021 & 15.6024 & 0.0008 & 18.0447 & 0.0008 & 2.1074 & 0.00004 & 1.1565 & 0.00001 \\
\hline & $38 *$ & 38.0281 & 0.0020 & 15.6023 & 0.0007 & 18.0451 & 0.0009 & 2.1074 & 0.00003 & 1.1566 & 0.00001 \\
\hline & 92 & 38.3593 & 0.0023 & 15.6218 & 0.0009 & 18.3844 & 0.0009 & 2.0866 & 0.00004 & 1.1768 & 0.00001 \\
\hline & $92 *$ & 38.3638 & 0.0018 & 15.6232 & 0.0006 & 18.3863 & 0.0007 & 2.0865 & 0.00004 & 1.1768 & 0.00001 \\
\hline & 170 & 38.4082 & 0.0019 & 15.6278 & 0.0007 & 18.4104 & 0.0007 & 2.0862 & 0.00004 & 1.1781 & 0.00001 \\
\hline & $170^{*}$ & 38.4066 & 0.0018 & 15.6277 & 0.0006 & 18.4096 & 0.0007 & 2.0862 & 0.00005 & 1.1780 & 0.00001 \\
\hline & 172 & 38.4015 & 0.0026 & 15.6263 & 0.0010 & 18.4110 & 0.0010 & 2.0858 & 0.00005 & 1.1782 & 0.00002 \\
\hline & 174 & 38.3974 & 0.0020 & 15.6270 & 0.0007 & 18.4055 & 0.0009 & 2.0862 & 0.00004 & 1.1778 & 0.00001 \\
\hline & 176 & 38.3866 & 0.0024 & 15.6255 & 0.0009 & 18.3991 & 0.0010 & 2.0864 & 0.00005 & 1.1775 & 0.00001 \\
\hline & 178 & 38.3762 & 0.0019 & 15.6233 & 0.0008 & 18.3930 & 0.0009 & 2.0864 & 0.00004 & 1.1773 & 0.00001 \\
\hline & 180 & 38.3702 & 0.0014 & 15.6216 & 0.0006 & 18.3899 & 0.0007 & 2.0865 & 0.00004 & 1.1772 & 0.00001 \\
\hline & 182 & 38.3719 & 0.0022 & 15.6231 & 0.0010 & 18.3884 & 0.0010 & 2.0867 & 0.00004 & 1.1770 & 0.00001 \\
\hline & $182 *$ & 38.3729 & 0.0017 & 15.6235 & 0.0007 & 18.3891 & 0.0007 & 2.0867 & 0.00004 & 1.1770 & 0.00001 \\
\hline & 184 & 38.3624 & 0.0021 & 15.6228 & 0.0008 & 18.3790 & 0.0008 & 2.0873 & 0.00004 & 1.1764 & 0.00001 \\
\hline & 187 & 38.3748 & 0.0022 & 15.6234 & 0.0008 & 18.3863 & 0.0009 & 2.0872 & 0.00004 & 1.1768 & 0.00001 \\
\hline & 189 & 38.3748 & 0.0024 & 15.6247 & 0.0008 & 18.3855 & 0.0010 & 2.0873 & 0.00004 & 1.1767 & 0.00001 \\
\hline & 193 & 38.4329 & 0.0023 & 15.6325 & 0.0008 & 18.4032 & 0.0009 & 2.0884 & 0.00004 & 1.1772 & 0.00001 \\
\hline & 195 & 38.4858 & 0.0015 & 15.6385 & 0.0005 & 18.42 & 0.0007 & 2.0886 & 0.00004 & 1.1783 & 0.00001 \\
\hline & $195 *$ & 38.4840 & 0.0017 & 15.6381 & 0.0006 & 18.42 & 0.0006 & 2.0886 & 0.00004 & 1.1783 & 0.00001 \\
\hline & 197 & 38.5294 & 0.0016 & 15.6450 & 0.0006 & 18.4533 & 0.0006 & 2.0879 & 0.00004 & 1.1795 & 0.00001 \\
\hline & $200 *$ & 38.5306 & 0.0019 & 15.6425 & 0.0007 & 18.4681 & 0.0007 & 2.0863 & 0.00004 & 1.1806 & 0.00001 \\
\hline & 200 & 38.5327 & 0.0016 & 15.6432 & 0.0006 & 18.4686 & 0.0006 & 2.0864 & 0.00004 & 1.1806 & 0.00001 \\
\hline & 220 & 38.4492 & 0.0019 & 15.6384 & 0.0007 & 18.4908 & 0.0008 & 2.0794 & 0.00004 & 1.1824 & 0.00001 \\
\hline & 412 & 38.8049 & 0.0025 & 15.6762 & 0.0009 & 18.9730 & 0.0011 & 2.0453 & 0.00005 & 1.2103 & 0.00002 \\
\hline \multirow[t]{13}{*}{ MIS } & 69.9 & 38.48663 & 0.00186 & 15.63528 & 0.00083 & 18.50578 & 0.00092 & 2.07972 & 0.00004 & 1.18359 & 0.00001 \\
\hline & 76.5 & 38.56519 & 0.00184 & 15.64418 & 0.00082 & 18.57075 & 0.00088 & 2.07669 & 0.00005 & 1.18708 & 0.00001 \\
\hline & 78.7 & 38.54759 & 0.00332 & 15.63986 & 0.00141 & 18.56503 & 0.00158 & 2.07636 & 0.00004 & 1.18703 & 0.00001 \\
\hline & 83.1 & 38.61125 & 0.00228 & 15.64727 & 0.00091 & 18.61642 & 0.00097 & 2.07407 & 0.00004 & 1.18974 & 0.00001 \\
\hline & 88 & 38.5753 & 0.0024 & 15.6411 & 0.0009 & 18.5909 & 0.0011 & 2.0750 & 0.00005 & 1.1886 & 0.00002 \\
\hline & 110 & 38.2657 & 0.0024 & 15.6109 & 0.0008 & 18.3112 & 0.0010 & 2.0897 & 0.00004 & 1.1730 & 0.00001 \\
\hline & 120 & 38.3471 & 0.0018 & 15.6168 & 0.0008 & 18.3852 & 0.0009 & 2.0858 & 0.00004 & 1.1773 & 0.00001 \\
\hline & 131 & 38.3694 & 0.0019 & 15.6239 & 0.0007 & 18.3873 & 0.0007 & 2.0867 & 0.00004 & 1.1769 & 0.00001 \\
\hline & 134 & 38.3684 & 0.0026 & 15.6236 & 0.0009 & 18.3851 & 0.0010 & 2.0869 & 0.00004 & 1.1768 & 0.00001 \\
\hline & 135 & 38.2948 & 0.0021 & 15.6165 & 0.0008 & 18.3241 & 0.0008 & 2.0899 & 0.00004 & 1.1734 & 0.00001 \\
\hline & 138 & 38.3719 & 0.0023 & 15.6232 & 0.0009 & 18.3865 & 0.0009 & 2.0870 & 0.00004 & 1.1769 & 0.00001 \\
\hline & 146 & 38.3716 & 0.0020 & 15.6219 & 0.0008 & 18.3886 & 0.0009 & 2.0867 & 0.00004 & 1.1771 & 0.00001 \\
\hline & 170 & 38.5086 & 0.0019 & 15.6394 & 0.0008 & 18.4658 & 0.0009 & 2.0854 & 0.00005 & 1.1807 & 0.00001 \\
\hline
\end{tabular}

\subsubsection{MIS-08-01b Core (MIS)}

The concentrations of lithogenic and conservative elements $(\mathrm{Sc}, \mathrm{Ti}$, and $\mathrm{Al}$ ) and the trace element $(\mathrm{Pb})$ were determined every $2 \mathrm{~cm}(\mathrm{n}=41)$ by High Resolution Inductively Coupled Plasma Mass Spectrometry (HR-ICP-MS) Thermo Element XR at the Observatoire Midi-Pyrénées (Toulouse, France) after complete dissolution of the $100 \mathrm{mg}$ of sample with a mixture of HNO3-HF-H202 in Savillex®beakers on a hot plate in a clean room (class 100). The standards (NIMT peat, ICHTJ, CTA-OTL1 oriental tobacco leaves, NIST tomato leaves 1573 and IAEA lichen 336) were used to assess the external analytical reproducibility. The limits of quantification were calculated from the intensity and standard deviation measurements of 6 blanks. Comparisons between reference values and measured values were satisfactory for $>90 \%$.

\subsection{Density}

Bulk density was determined by taking 1-cm-thick plugs with a 2-cm diameter cylinder. The peat was dried until constant weight and the density was calculated as follows:

$$
\text { Density }\left(\mathrm{g} \mathrm{cm}^{-3}\right)=\text { dry weight }(\mathrm{g}) / \text { sample volume }\left(\mathrm{cm}^{3}\right)
$$




\subsection{Calculation of Enrichment Factor and Accumulation Rate of $\mathrm{Pb}$}

The variation in trace metal concentrations can be explained by changes in supply, changes in their origin (natural or anthropogenic sources), differences in peat mass accumulation and the quantity of mineral material in the peat. One approach to separate the influence of anthropogenic sources from natural mineral material is to calculate an enrichment factor $\left(\mathrm{EF}_{\mathrm{Pb}}\right)$ for each metal by using a conservative element (e.g., Ti, Sc, $\mathrm{Al}$ ) indicative of the mineral material amount. In this study, the Sc values were used to calculate $\mathrm{EF}_{\mathrm{Pb}}$ as follows:

$$
E F_{P b}=\frac{\left(\frac{[\mathrm{Pb}]}{[\mathrm{Sc}]}\right)_{\text {peat }}}{\left(\frac{[\mathrm{Pb}]}{[\mathrm{Sc}]}\right)_{\text {local }}}
$$

where $\left([\mathrm{Pb}]\right.$ and $([\mathrm{Sc}])_{\text {Peat }}$ are the respective total concentrations of $\mathrm{Pb}$ and $\mathrm{Sc}$ measured in the peat samples; $([\mathrm{Pb}] \text { and }[\mathrm{Sc}])_{\text {local }}$ represent the abundance measured at the bottom section of the peat, by averaging the value of 45 samples taken from 600 to $750 \mathrm{~cm}$ in MIS core and the value of 250 samples taken from 450 to $535 \mathrm{~cm}$ in CLE core, representing the natural pre-anthropic elemental background (Allan, unpublished data).

The use of trace element accumulation rates (AR) instead of concentrations or enrichment factors is more appropriate, as variations in net peat accumulation and decomposition are taken into account by the AR. The peat accumulation rate varies within a profile, and differences between cores profiles can be caused by differences in surface growth rates and in decomposition rates because peat compaction increases with decomposition. Based on an age-depth model, density and [Pb], the $\mathrm{Pb}$ accumulation rate can be calculated as follows:

$$
\mathrm{Pb} \mathrm{AR}\left(\mathrm{mg} \mathrm{m}^{-2} \mathrm{yr}^{-1}\right)=[\mathrm{Pb}]\left(\mu \mathrm{g} \mathrm{g}^{-1}\right) \times \text { density }\left(\mathrm{g} \mathrm{cm}^{-3}\right) \times \text { accumulation rate }\left(\mathrm{cm} \mathrm{yr}^{-1}\right) \times 10
$$

\section{Results and Discussion}

\subsection{Density, Elemental Concentrations and $\mathrm{Pb}$ Isotope Ratios}

In core CLE, dry bulk density ranges from 0.05 to $0.17 \mathrm{~g} \mathrm{~cm}^{-3}$ with a mean of $0.1 \mathrm{~g} \mathrm{~cm}^{-3}$. In core MIS, density varies from 0.03 to $0.1 \mathrm{~g} \mathrm{~cm}^{-3}$ and average of $0.05 \mathrm{~g} \mathrm{~cm}^{-3}$. These values vary between 0.03 and $0.05 \mathrm{~g} \mathrm{~cm}^{-3}$ from the lower part of the core at 180-120 cm (from $500 \mathrm{BC}$ to AD 120), and they increase to the upper peat section (Figure 2).

In core $\mathrm{CLE}$, the conservative elements $(\mathrm{Al}, \mathrm{Sc}$ and $\mathrm{Ti})$ concentrations display similar variations (Figure 2). These three elements measured along the core (from 165-550 $\mathrm{cm}$ ) are significantly correlated $\left(\mathrm{r}_{\mathrm{Al}-\mathrm{Ti}}=0.92, \mathrm{r}_{\mathrm{Al}-\mathrm{Sc}}=0.96, \mathrm{r}_{\mathrm{Sc}-\mathrm{Ti}}=0.89 ; p\right.$-values $\left.<0.0001\right)$. Between 165 and $225 \mathrm{~cm}$, the Al values vary between 2 and $300 \mu \mathrm{g} \mathrm{g}^{-1}$ with a mean of $125 \mu \mathrm{g} \mathrm{g}^{-1}$, from 0.01 to $0.16 \mu \mathrm{g} \mathrm{g}^{-1}$ with a an average of $0.03 \mu \mathrm{g} \mathrm{g}^{-1}$ for Sc, and from 0.15 to $69 \mu \mathrm{g} \mathrm{g}^{-1}$ with a mean of $7 \mu \mathrm{g} \mathrm{g}^{-1}$ for Ti. The Pb content can be described in four phases evolution: (i) very low concentrations (mean $<0.2 \mu \mathrm{g} \mathrm{g}^{-1}$ ) until c. $220 \mathrm{~cm}$ (80 BC); (ii) a first phase of increase with four peaks (of $5-10 \mu \mathrm{g} \mathrm{g}^{-1}$ ) until $188 \mathrm{~cm}$ (AD 100); (iii) a sharp, brief, decline to very low concentrations followed by a second phase of relatively high concentrations $\left(\max [\mathrm{Pb}]=9 \mu \mathrm{g} \mathrm{g}^{-1}\right.$ ) between 187 and $181 \mathrm{~cm}$; and (iv) a return to low Pb values after $180 \mathrm{~cm}$-depth (Figure 2).

In core MIS, $\mathrm{Al}, \mathrm{Sc}$ and Ti concentrations display similar variations (Figure 2). Highly significant correlations $\left(\mathrm{r}_{\mathrm{Al}-\mathrm{Ti}}=0.92, \mathrm{r}_{\mathrm{Al}-\mathrm{Sc}}=0.93, \mathrm{r}_{\mathrm{Sc}-\mathrm{Ti}}=0.88 ; p\right.$-values $<0.0001, p$-values $\left.<0.0001\right)$ were calculated between those three elements measured along the core (from top to $735 \mathrm{~cm}$ ). In this study (from 90 to $180 \mathrm{~cm}$ ), the $\mathrm{Al}$ values vary between 430 and $1535 \mu \mathrm{g} \mathrm{g}^{-1}$ with a mean of $770 \mu \mathrm{g} \mathrm{g}^{-1}$. The Sc values range between 0.10 and $0.23 \mu \mathrm{g} \mathrm{g}^{-1}$ with an average of $0.16 \mu \mathrm{g} \mathrm{g}^{-1}$, and Ti values vary from 20 to $155 \mu \mathrm{g} \mathrm{g}^{-1}$ with a mean of $30 \mu \mathrm{g} \mathrm{g}^{-1}$. The Pb content shows five phases: (i) low low concentrations until c. $160 \mathrm{~cm}$ (280 BC); (ii) a slight increase, but remaining almost constant between c. 160 and c. 140 
cm (280-70 BC); (iii) high values between c. 140 and c. 120 cm (from 70 BC to AD 180); (iv) and (v) a gradual return to very low concentrations until $87 \mathrm{~cm}$ (Figure 2). The similarity between the $\mathrm{Al}, \mathrm{Sc}$ and Ti profiles confirms that these elements are not affected by any diagenetic process (immobile) and can be used to calculate the $\mathrm{Pb}$ enrichment factor.

Table 1 summarizes results of $\mathrm{Pb}$ isotope analyses in both cores CLE and MIS. In core CLE, the ${ }^{206} \mathrm{~Pb} /{ }^{207} \mathrm{~Pb}$ ratio shows two main ranges: from $400 \mathrm{BC}$ to $170 \mathrm{AD}$, the ratio drops from 1.182 to $1.764 \pm 0.00001$; and from $\mathrm{AD} 200$ to $\mathrm{AD} 395$, the ratio increases from 1.177 to $1.780 \pm 0.00001$ (Figure 2). In core MIS, ${ }^{206} \mathrm{~Pb} /{ }^{207} \mathrm{~Pb}$ ratio decreases from 1.180 to $1.173 \pm 0.00001$ in the interval from $325 \mathrm{BC}$ to $\mathrm{AD} 30$, then it increases to $1.188 \pm 0.00001$ at $\mathrm{AD} 500$.
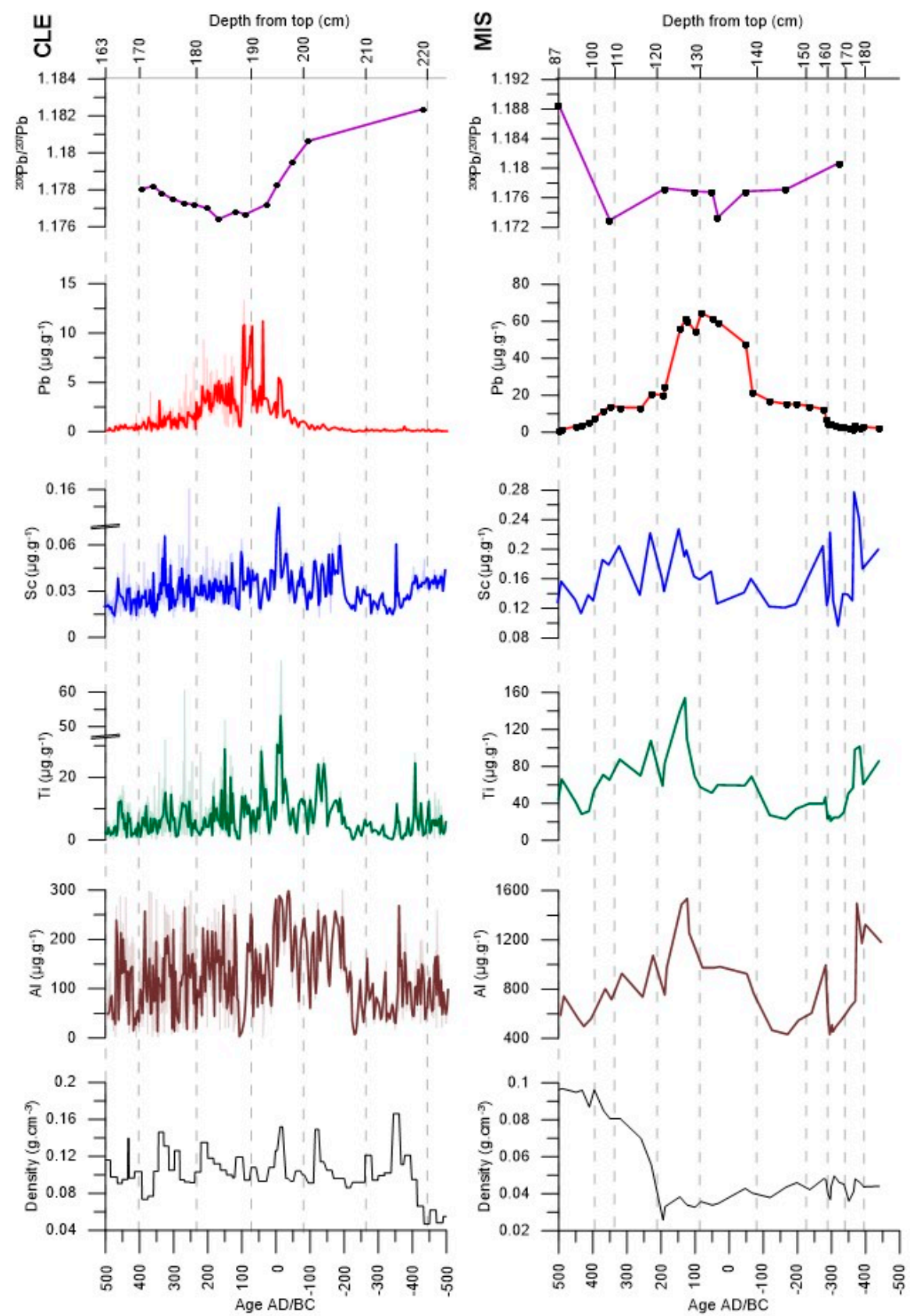

Figure 2. Evolution of density, elemental concentrations ( $\mathrm{Al}, \mathrm{Ti}, \mathrm{Sc}$ and $\mathrm{Pb}$ ), and radiogenic isotope ${ }^{207} \mathrm{~Pb} /{ }^{206} \mathrm{~Pb}$ ratios versus age and depth in CLE and MIS cores. Light lines indicate elemental concentrations and dark lines represent mean concentrations values. 


\subsection{Enrichment Factor of $\mathrm{Pb}$ and Accumulation Rate ( $\mathrm{Pb} A \mathrm{R}$ )}

The lithogenic elements (e.g., Al, Sc and Ti) were used as conservative elements because these elements are well above the limit of detection for both cores and resistant to chemical weathering, even in the acid environment of the peatland $[65,66]$. The calculated EF values are depending from the lithogenic element content used, because the heterogeneity of the deposits and sources of the dust. As the three conservative elements (Al, Sc and Ti) measured in both cores are highly correlated, only the $\mathrm{Sc}$ content was used to calculate $\mathrm{EF}_{\mathrm{Pb}}$. An EF value close/equal to 1 indicates that the relative concentration of a given element is identical to that which is present in the lower peat sections (natural sources). An EF values greater than 1 indicate the influence of anthropogenic sources. In the core $\mathrm{CLE}, \mathrm{EF}_{\mathrm{Pb}}$ values vary from 0.5 to 115 and from 2 to 105 for the core MIS (Figure 3). In both cores, $\mathrm{EF}_{\mathrm{Pb}}$ values remain low from the 500 to $200 \mathrm{BC}$ period and increase to reach a maximum between AD 50 and AD 225 for CLE and between 60 BC and AD 200 for MIS. Finally, EF ${ }_{P b}$ values decrease toward the upper section of cores. The location and assigned chronology of the maximum $\mathrm{EF}_{\mathrm{Pb}}$ differ in each core. Nevertheless, the increase in $\mathrm{EF}_{\mathrm{Pb}}$ values in each core is coincident with the period of Roman mining activities. However, the use of EF is more complicated becauce it is depends on the biosphere, hydrosphere and pedospheres and the human interference with element cycles at both local and regional scales.

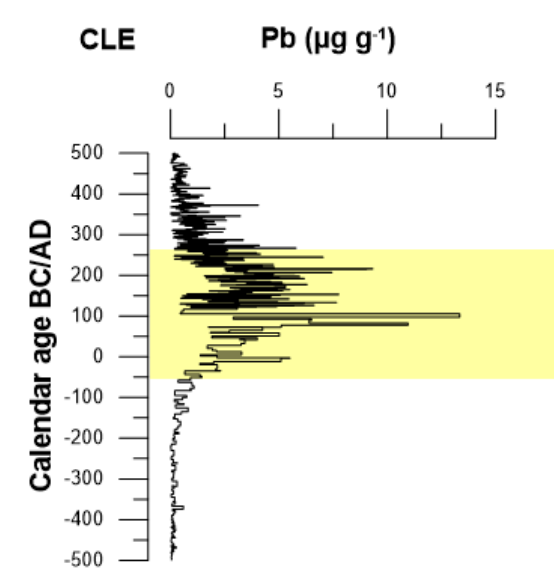

$\mathrm{Pb}\left(\mu \mathrm{g} \mathrm{g}^{-1}\right)$

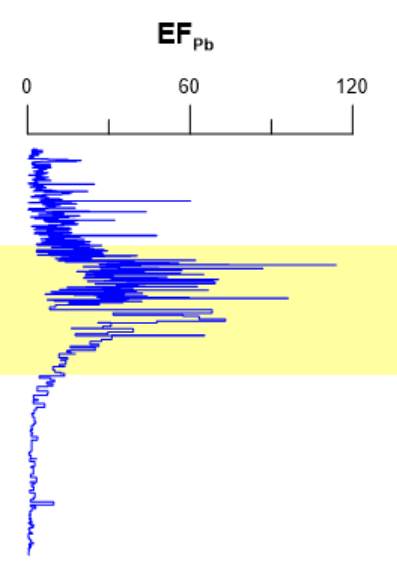

$\mathrm{EF}_{\mathrm{Pb}}$
$\operatorname{Pb}$ AR (mg m $\left.{ }^{-2} \mathrm{yr}^{-1}\right)$

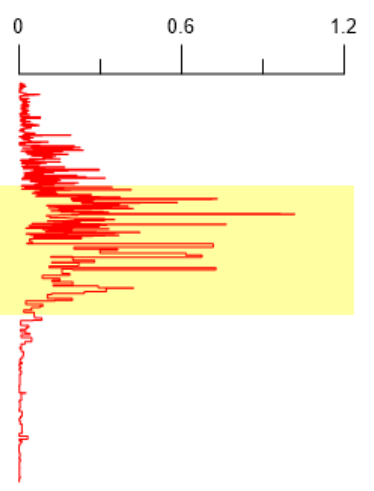

$\operatorname{Pb}$ AR $\left(\mathrm{mg} \mathrm{m}^{-2} \mathrm{yr}^{-1}\right)$

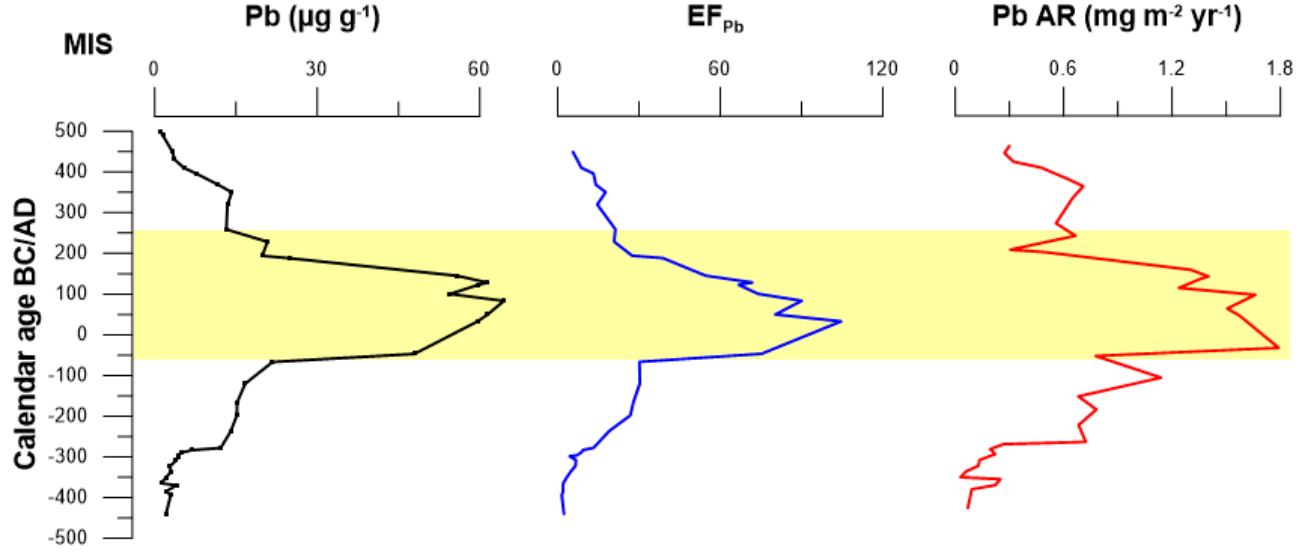

Figure 3. Summary of $\mathrm{Pb}$ concentration, $\mathrm{EF}_{\mathrm{Pb}}$, and calculated $\mathrm{Pb} \mathrm{AR}$ (in $\mathrm{mg} \mathrm{m}^{-2} \mathrm{yr}^{-1}$ ) for CLE and MIS cores. The yellow zone corresponds to the zenith Roman Empire.

Samples from the peat sections between 225 and $200 \mathrm{~cm}$ in core CLE and between 195 and 150 in core MIS (from 500 to $100 \mathrm{BC}$ ) were considered to calculate Pre-Roman Pb AR. The Pre-Roman period $\mathrm{Pb} \mathrm{AR}$ was $0.1 \mathrm{mg} \mathrm{m}^{-2} \mathrm{yr}^{-1}$ for CLE and $\mathrm{Pb} \mathrm{AR}=0.4 \mathrm{mg} \mathrm{m}^{-2} \mathrm{yr}^{-1}$ for MIS. In core CLE, the Pb AR remains lower than $0.15 \mathrm{mg} \mathrm{m}^{-2} \mathrm{yr}^{-1}$ from 500 to $80 \mathrm{BC}$ (Figure 3), then it increases from the inception of the Roman period at $50 \mathrm{BC}$ to reach a maximum of more than $0.7 \mathrm{mg} \mathrm{m}^{-2} \mathrm{yr}^{-1}$ between AD 70 and 
$\mathrm{AD}$ 215. Then, $\mathrm{Pb}$ AR decreases to less than $0.02 \mathrm{mg} \mathrm{m}^{-2} \mathrm{yr}^{-1}$ at the end of Roman period. In core MIS, the $\mathrm{Pb}$ AR remains lower than $0.4 \mathrm{mg} \mathrm{m}^{-2} \mathrm{yr}^{-1}$ from 450 to $80 \mathrm{BC}$ (Figure 3). Then, $\mathrm{Pb}$ AR increases to reach a maximum of more than $1.2 \mathrm{mg} \mathrm{m}^{-2} \mathrm{yr}^{-1}$ between $50 \mathrm{BC}$ and AD 150. Since then, the $\mathrm{Pb}$ AR decreases to less than $0.3 \mathrm{mg} \mathrm{m}^{-2} \mathrm{yr}^{-1}$ at the end of Roman period (i.e., after AD 350). During the Roman period, the mean $\mathrm{Pb}$ AR shows values 17-80 times higher than the natural background ( $<0.003 \mathrm{mg} \mathrm{m}^{-2} \mathrm{yr}^{-1}$ in CLE and $<0.07 \mathrm{mg} \mathrm{m}^{-2} \mathrm{yr}^{-1}$ in MIS).

An intra-site variability in $\mathrm{Pb}$ AR values is observed when CLE and MIS cores are compared. During both the pre-Roman and Roman periods $\mathrm{Pb}$ AR at MIS is higher than at CLE. However, they both indicate similar chronologies of the $\mathrm{Pb} \mathrm{AR}$. As the two bogs are influenced by similar climate regime (nearby bogs located ca. $8 \mathrm{~km}$ of distance and similar altitudes), an actual difference in $\mathrm{Pb}$ AR values at the two sites is unlikely. Such a difference may be explained by the within-bog spatial heterogeneity and/or the $\mathrm{Pb}$ measurement resolution $[2,67,68]$. The difference between hummocks and hollows is well established, where hummocks are known to have higher interception of atmospheric particles [2]. Indeed, the MIS core was taken from a hummock and CLE was taken between a hummock and a hollow. Therefore, MIS may have better trapped atmospherically deposited $\mathrm{Pb}$ than the CLE bog due to a favorable micro-topography. The $\mathrm{Pb}$ concentrations were measured in the core CLE by LA-ICP-MS with a resolution of $1 \mathrm{~mm}$ and by ICP-MS in the core MIS with a lower resolution of $2 \mathrm{~cm}$. By using nine hummock cores collected on one bog, Bindler el al. [68] suggested that the micro-climate, microtopography and plant community can play an important role in different $\mathrm{Pb}$ accumulation rates. Allan et al. [69] showed, by studying $\mathrm{Hg}$ accumulation rates in four cores recorded in Misten peatland over 1500 years, that the potential factor that could contribute to the intra-site variation is the inhomogeneous peat accumulation rates across time and space. This suggests that particle deposition recorded in our peat cores could be affected by the micro-topography, heterogeneous peat accumulation rate, and both resolution and the analytical techniques used for $\mathrm{Pb}$ measurements in this study.

The mean natural background of $\mathrm{Pb}$ AR (before $500 \mathrm{BC}, 0.003 \pm 0.001 \mathrm{mg} \mathrm{m}^{-2} \mathrm{yr}^{-1}$; unpublished data) for CLE is similar to published values of $0.007 \pm 0.002 \mathrm{mg} \mathrm{m}^{-2} \mathrm{yr}^{-1}$ from $2000 \mathrm{BC}$ to $900 \mathrm{BC}$ for an England peatland [1], $0.01 \pm 0.003 \mathrm{mg} \mathrm{m}^{-2} \mathrm{yr}^{-1}$ obtained from 5000 to $3000 \mathrm{BC}$ for a Swiss peat [5]. Such comparison suggests that $\mathrm{Pb}$ AR values in CLE and MIS cores before $500 \mathrm{BC}$ correspond to deposition of geogenic $\mathrm{Pb}$. The large increase in $\mathrm{Pb} \mathrm{AR}$ recorded in CLE and MIS cores (from 50 BC to AD 200) is in good agreement with other studies on European peatlands which show a peak due to Roman $\mathrm{Pb}$ mining $[1,5,13]$. The mean $\mathrm{Pb} \mathrm{AR}$ in the CLE and MIS peat cores is within the range $0.24-1.18 \mathrm{mg} \mathrm{m}^{-2} \mathrm{yr}^{-1}$ (50 BC-AD 200): such values are 17-80 times the natural background values. This is in good agreement with the maximum values recorded in Spanish peat bogs $\left(0.3-0.9 \mathrm{mg} \mathrm{m}^{-2} \mathrm{yr}^{-1}\right)$ which are 10-30 times the background values $\left(0.025-0.031 \pm 0.015 \mathrm{mg} \mathrm{m}^{-2} \mathrm{yr}^{-1}\right)$ from $550 \mathrm{BC}$ to AD 500 [13,25]. In a Swiss peat bog core, the maximum $\mathrm{Pb}$ AR is 37 times the background value for the Roman period [5]. Le Roux et al. [1] also showed that the maximum $\mathrm{Pb}$ AR value $\left(0.22 \mathrm{mg} \mathrm{m}^{-2} \mathrm{yr}^{-1}\right)$ during the Roman period was 34 times higher than that of the pre-Roman period. In peat bogs cores from southern Black forest-SW Germany, Le Roux et al. [38] showed that the $\mathrm{Pb}$ AR is more than 40 times the background values $\left(0.02-0.03 \pm 0.01 \mathrm{mg} \mathrm{m}^{-2} \mathrm{yr}^{-1}\right)$. We can conclude that the Pb AR and chronologies in the CLE and MIS cores are consistent with those reported for other European peat records.

\subsection{Identification of Pb Sources}

The ${ }^{206} \mathrm{~Pb} /{ }^{207} \mathrm{~Pb}$ ratios are plotted against the reciprocal of the $\mathrm{Pb}$ content in Figure 4 in order to document any change in the isotopic $\mathrm{Pb}$ composition consistent with a contamination in $\mathrm{Pb}$. The evolution for CLE and MIS core shows a significant relationship between $\mathrm{Pb}$ content and isotopic composition. The decrease in the isotopic ratios throughout both cores is associated with an increase in $\mathrm{Pb}$, suggesting a progressive input of $\mathrm{Pb}$ from pollution sources (potential sources are described below). The potential sources of $\mathrm{Pb}$ contamination are discussed below. 


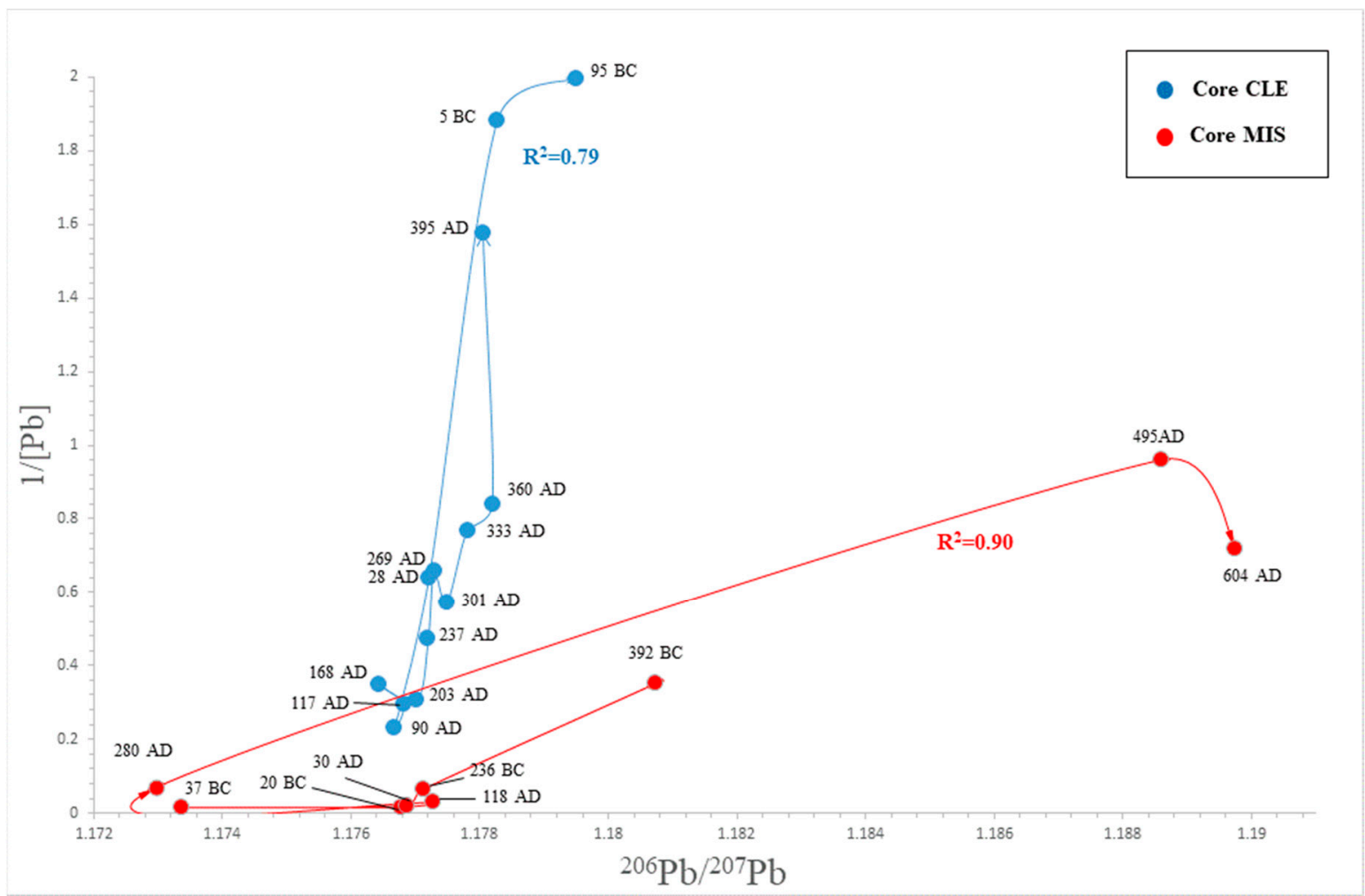

Figure 4. Evolution of ${ }^{206} \mathrm{~Pb} /{ }^{207} \mathrm{~Pb}$ ratios in CLE and MIS core samples versus $1 /[\mathrm{Pb}]$.

Roman mining and metallurgical activities all over NW-SW Europe and around the Mediterranean Sea increased significantly the amount of atmospheric $\mathrm{Pb}[5,15,20,61,70]$. The $\mathrm{Pb}$ isotope ratios deposited in CLE and MIS peat cores vary from 1.729 to 1.178 for ${ }^{206} \mathrm{~Pb} /{ }^{207} \mathrm{~Pb}$ ratios and from 2.086 to 2.089 for ${ }^{208} \mathrm{~Pb} /{ }^{206} \mathrm{~Pb}$ ratios (Figure $5 \mathrm{~A}$ ).

In order to identify the source of lead, $\mathrm{Pb}$ isotope data from this study are compared with Belgian ores and $\mathrm{Pb}-\mathrm{Zn}$ ores from the Verviers syncline exploited during the Roman period [71,72], Germany ores [73], Benelux modern aerosols [74], the Belgian pre-industrial background [43] and the Upper Continental Crust [75]. In the binary diagram ${ }^{208} \mathrm{~Pb} /{ }^{206} \mathrm{~Pb}$ vs. ${ }^{206} \mathrm{~Pb} /{ }^{207} \mathrm{~Pb}$, most of the CLE and MIS core data plot in the isotope field defined by Belgian ores [71,72], Eifel ores [73], $\mathrm{Pb}-\mathrm{Zn}$ ores from the Verviers syncline [71,72] (Figure 5A). Most samples from the post/pre-Roman period have mixed Pb isotopic signatures between those of Belgian ores and that of the Belgian pre-industrial background. The lowest sample (412 cm-3070 BC) shows good agreement with upper continental crust values and Belgian pre-industrial background. The $\mathrm{Pb}$ isotope ratios measured in CLE and MIS samples for the Roman period between $40 \mathrm{BC}$ and $\mathrm{AD} 300$ correspond to the isotopic fields of the $\mathrm{Pb}-\mathrm{Zn}$ ores of the Verviers syncline, Belgian ores and the Eifel ores [73]. Following the Roman period, the next phase of change is characterized by an increase in $1 /[\mathrm{Pb}]$ and ${ }^{206} \mathrm{~Pb} /{ }^{207} \mathrm{~Pb}$ ratios values reflecting the decline of the Roman mining activities (Figure 4). This drop has already been well documented in other European peat bogs [2,76]. Note our results are consistent with those obtained by De Vleeschouwer et al. [43] in a former core recovered in the Misten bog and by Renson et al. [44] from peat cores (RC1) in the Hautes Fagnes Plateau (Figure 5A). The CLE and MIS peat samples are plotted along with those of various European $\mathrm{Pb}$ ores [77], supporting the influence of regional anthropogenic sources (Figure 5B). The $\mathrm{Pb}$ isotopic ratios of this study show that the Clefaye and Misten peats are influenced by a mixture of local and regional anthropogenic sources. 

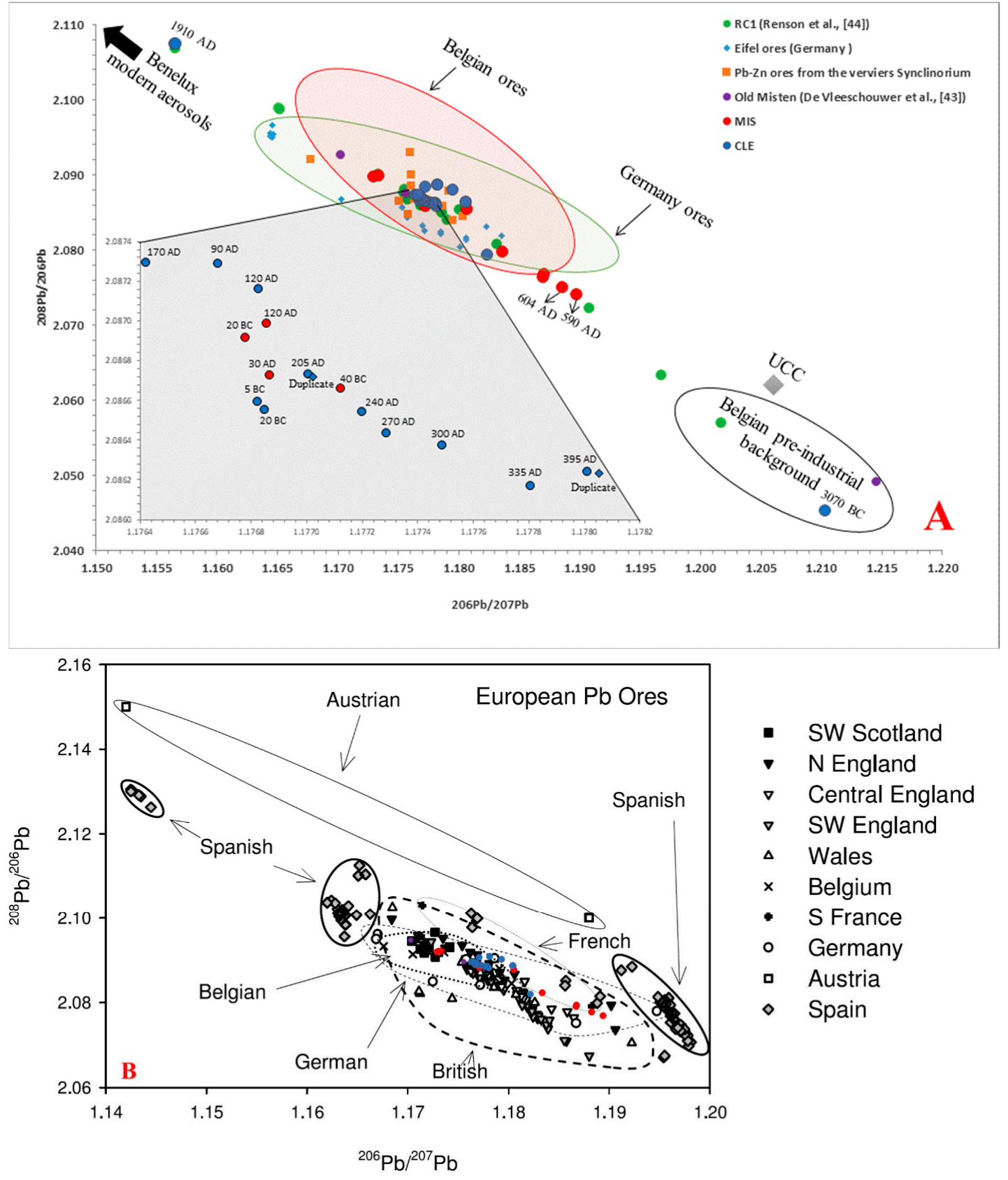

Figure 5. (A) Binary diagram ${ }^{206} \mathrm{~Pb} /{ }^{207} \mathrm{~Pb}$ vs ${ }^{208} \mathrm{~Pb} /{ }^{206} \mathrm{~Pb}$. Benelux modern from Bollhöfer and Rosman [74]. Belgian ores and Pb-Zn ores from the Verviers Synclinorium from Cauet and Herbosh [71] and Dejonghe [72]. German ores from Durali-Mueller et al. [73]. Belgian pre-industrial background from this study and De Vleeschouwer et al. [43] and upper continental crust from Millot et al. [75]. (B) Plot of ${ }^{206} \mathrm{~Pb} /{ }^{207} \mathrm{~Pb}$ vs ${ }^{208} \mathrm{~Pb} /{ }^{206} \mathrm{~Pb}$ ratios for Roman samples recorded from CLE and MIS cores and European $\mathrm{Pb}$ ores [76].

\subsection{Temporal Evolution of Pb Contamination}

The increased atmospheric lead deposition in the Belgian peatland records displays significant variability during the Roman period, with maxima of $\mathrm{Pb}$ concentrations observed between $80 \mathrm{BC}$ and AD 230 (Figure 6). At least six local maxima are identifiable, centered at $\sim 50$ BC, AD 5, AD 75, $\sim \mathrm{AD} 130, \sim \mathrm{AD} 180$, and $\sim \mathrm{AD} 215$, pointing to changes in the intensity of mining and metallurgy activities in the area. This pattern is also followed by higher Pb enrichment factors (Figure 3) in parallel 
with a decrease in the ${ }^{206} \mathrm{~Pb} /{ }^{207} \mathrm{~Pb}$ ratio (Figure 2). The inception and end of $\mathrm{Pb}$ contamination period reflects the rise and subsequent fall of the Roman Empire in Western Europe. The Pb concentrations from Belgian peat records increase since ca. $300 \mathrm{BC}$ for MIS and $100 \mathrm{BC}$ for CLE to reach a maximum at $\sim 50 \mathrm{BC}$ (Figure 6), coinciding with the period of Late Iron Age and Early Roman Empire, related to Celtic mining activity [40,42]. The Celtic people established in South Belgium from 480 BC to 27 BC and developed gold extraction from river sediments and arkose mines [40,42,46]. The gold mining activity is attested by more than thousand archeological sites in Southeast Belgium [46]. Between $\mathrm{AD} 75$ and $\mathrm{AD} 230$, corresponding to the zenith of the Roman Empire, the Pb concentrations increase to a maximum $>15 \mu \mathrm{g} \mathrm{g}^{-1}$ for CLE and $>60 \mu \mathrm{g} \mathrm{g}^{-1}$ for MIS (Figrue 6). During this period, $\mathrm{Pb} \mathrm{AR}$ and $\mathrm{EF}_{\mathrm{Pb}}$ are higher and ${ }^{206} \mathrm{~Pb} /{ }^{207} \mathrm{~Pb}$ ratios show lower radiogenic values $\left({ }^{206} \mathrm{~Pb} /{ }^{207} \mathrm{~Pb}\right.$ up to 1.173$)$. The increase of lead pollution detected in the Belgian peatlands is synchronous with intense mining and metallurgical activity that took place all over NW Europe and around the Mediterranean Sea. In addition, a local pollution may have occurred in MIS and CLE sites. The Pb isotopic values of CLE and MIS samples $\left({ }^{206} \mathrm{~Pb} /{ }^{207} \mathrm{~Pb} \sim 1.170-1.180\right)$ from $20 \mathrm{BC}$ to AD 400 show good agreement with the isotopic field of the Belgian $\mathrm{Pb}-\mathrm{Zn}$ ores $\left({ }^{206} \mathrm{~Pb} /{ }^{207} \mathrm{~Pb} \sim 1.167-1.180\right)$. In Belgium, there is no historical, archaeological evidence for Roman $\mathrm{Pb}-\mathrm{Zn}$ mining. However, in previous studies of a peat column taken nearby an archaeological site constituted by a Roman road and peat bog core in the Hautes Fagnes, Renson et al. [44] and De Vleeschouwer el al. [43] found and dated very high Pb concentrations (up to 90-135 $\mathrm{\mu g} \mathrm{g}^{-1}$ ) that reflect local pollution linked to the Roman road [44]. Additionally, the Pb isotopic composition found by De Vleeschouwer el al. [43] and Renson et al. [44] is in good agreement with isotopic composition of $\mathrm{Pb}-\mathrm{Zn}$ ores from the Verviers syncline located $15 \mathrm{~km}$ northwards to the Hautes Fagnes Plateau.

Many other studies have reported $\mathrm{Pb}$ contamination dating from the Roman period, including peat bogs $[1,13,77]$, lake sediments [78-80] and ice cores [81,82] (Figure 6). During this interval period, production of $\mathrm{Pb}$ in Europe and Asia reached approximately 80,000 tons per year [18]. It has been estimated that as much as $5 \%$ of this $\mathrm{Pb}$ production might have been emitted to the atmosphere [83] and was registered in most natural archives from both low and high latitudes. By using peat and lake sediments cores recorded from southern Sweden, Brännvall et al. [70] showed an increase in atmospheric $\mathrm{Pb}$ deposition during the Roman period with high $\mathrm{Pb}$ AR detected around $\mathrm{AD} 0$ with ${ }^{206} \mathrm{~Pb} /{ }^{207} \mathrm{~Pb}$ values $=1.17$. Le Roux et al. [1] showed, by using a peat bog core from England, a dramatic increase in $\mathrm{Pb}$ AR around 0 AD and AD 140. During both intervals, the ${ }^{206} \mathrm{~Pb} /{ }^{207} \mathrm{~Pb}$ ratio values are around 1.177. Kylander el al. [13] demonstrated that high $\mathrm{Pb}$ concentrations $\left(>5 \mu \mathrm{g} \mathrm{g}^{-1}\right)$ are detected between $\mathrm{AD} 45$ and $\mathrm{AD} 190$ with ${ }^{206} \mathrm{~Pb} /{ }^{207} \mathrm{~Pb}$ ratio values $<1.185$. In La Molina mire $\mathrm{Pb}$ record, Martinez Cortizas et al. [84] demonstrated that the atmospheric metal pollution shows six maxima centred at 20 BC, AD 65, AD 140, AD 180, AD 320 and AD 440, pointing to changes in the intensity of mining and metallurgy in the NW Spain. The maxima of Pb concentrations ( $50 \mathrm{BC}, \mathrm{AD} 5, \sim \mathrm{AD} 75$, $\sim \mathrm{AD} 130, \sim \mathrm{AD} 180$, and $\sim \mathrm{AD} 215$ ) observed in CLE and MIS cores are in good agreement with similar studies in Europe. Our results from CLE and MIS cores are consistent with the timing of documented Roman lead deposition in other lake, peatland and ice archives (Figure 6). Most studies showed a peak of lead concentration somewhere between 50 BC and AD 200. The increase in atmospheric $\mathrm{Pb}$ concentration, recorded around $200 \mathrm{BC}$ in England [1,77] and Spain [13], indicates earlier Pb extraction (pre-Roman mining activities) in the British Isles and Spain. Compared to other areas in Europe, there is no evidence of earlier phases of mining/metallurgy in Belgium yet. Our geochemical results yield evidence of local and regional environmental contamination in the Belgian peats due to mining activities that began during the Roman period. 


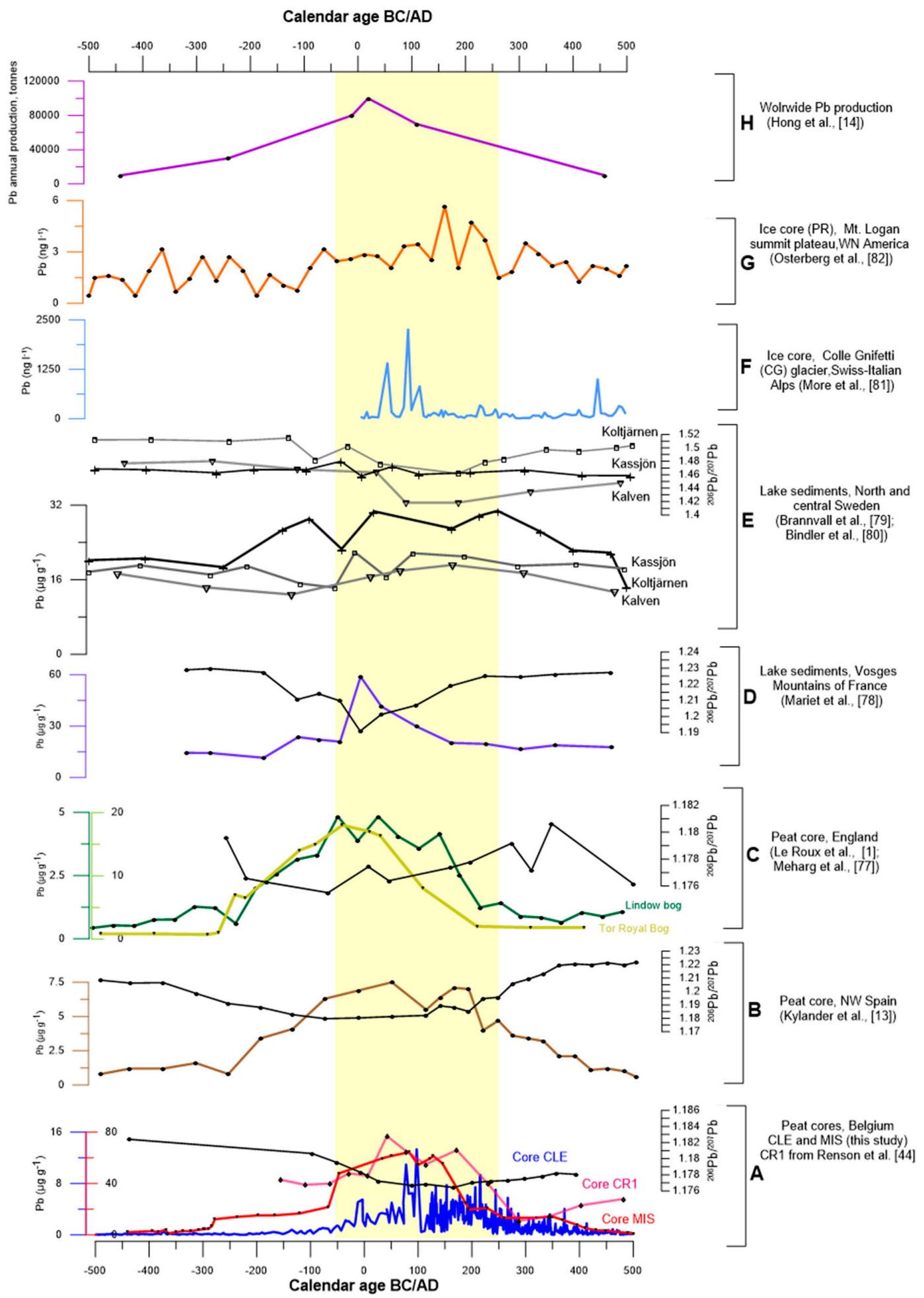

Figure 6. $\mathrm{Pb}$ concentrations and ${ }^{206} \mathrm{~Pb} /{ }^{207} \mathrm{~Pb}$ ratio record from: A. Belgian peat cores for the period from 500 BC to AD 500 [44], B. NW Spain peat core [13], C. England peat cores [1,77], D. French lake sediments [78], E. Swedish lake sediments [79,80], F. Suiss ice core [81], G. Canadian ice core [82]. The historical production of lead (H) during Roman period [14].Yellow zone corresponds to zenith Roman Empire. 


\section{Conclusions}

The $\mathrm{Pb}$ concentrations, $\mathrm{EF}_{\mathrm{Pb}}$ and $\mathrm{Pb} \mathrm{AR}$ as well as the isotopic composition of the accumulated $\mathrm{Pb}$ enabled an annual-decadal reconstruction of the chronology of atmospheric $\mathrm{Pb}$ pollution of the Belgian records from $500 \mathrm{BC}$ to $\mathrm{AD} 500$. The highest $\mathrm{Pb}$ concentration and $\mathrm{EF}_{\mathrm{Pb}}$ were observed between $50 \mathrm{BC}$ and AD 215 (15-60 $\mathrm{\mu g} \mathrm{g}^{-1}, 105-115$; respectively). Pre-Roman Pb AR averaged 0.1-0.4 $\mathrm{mg} \mathrm{m}^{-2} \mathrm{yr}^{-1}$ from $500 \mathrm{BC}$ to $100 \mathrm{BC}$, the Roman $\mathrm{Pb}$ AR reached a maximum from 0.7 to $1.2 \mathrm{mg} \mathrm{m}^{-2} \mathrm{yr}^{-1}$ between $50 \mathrm{BC}$ and $\mathrm{AD}$ 215. The amplitude of Pb AR and chronologies in the CLE and MIS cores are consistent with those reported for other European peat records, reflecting the influence of local Belgian ores and regional European pollution. More precisely, Belgian peatland cores recorded specific phases that are in agreement with mining Roman activities in Germany, France, Spain and Sweden. High PbAR values during the Roman period were primarily caused by mining and metallurgical activities. This study contributes to the European datasets for pollution reconstruction during the Roman period.

Author Contributions: M.A. and N.F. designed the experiments, N.M. carried out $\mathrm{Pb}$ isotopes data analysis. D.L.P., B.G., and S.V. participated in writing and correcting of this manuscript. M.A. prepared the manuscript with contributions from all co-authors.

Acknowledgments: This study was funded by the FNRS (HOPES project, N 23612574). We thank all the persons who contribute to this work, especially Joel Otten, Ahounta Djidoumalbaye and Hicham El Idrissi for their help during fieldwork; Luc André and Laurence Monin from RMCA in Tervuren (Belgium) for LA-ICP-MS analyses and Gael le Roux from EcoLab in Toulouse (France) for HR- ICP-MS analyses.

Conflicts of Interest: The authors declare no conflict of interest

\section{References}

1. Le Roux, G.; Weiss, D.; Grattan, J.; Givelet, N.; Krachler, M.; Cheburkin, A.; Rausch, N.; Kober, B.; Shotyk, W. Identifying the sources and timing of ancient and medieval atmospheric lead pollution in England using a peat profile from Lindow bog, Manchester. J. Environ. Monit. 2004, 6, 502-510. [CrossRef] [PubMed]

2. Allan, M.; Le Roux, G.; De Vleeschouwer, F.; Bindler, R.; Fagel, N. High-resolution reconstruction of atmospheric deposition of trace metals and metalloids since 300 years in Belgium recorded by ombrotrophic peat cores (Hautes-Fagnes, Belgium). Environ. Pollut. 2013, 178, 1-14. [CrossRef] [PubMed]

3. Pacyna, E.G.; Pacyna, J.M.; Fudala, J.; Strzelecka-Jastrzab, E.; Hlawiczka, S.; Panasiuk, D.; Nitter, S.; Pregger, T.; Pfeiffer, H.; Friedrich, R. Current and future emissions of selected heavy metals to the atmosphere from anthropogenic sources in Europe. Atmos. Environ. 2007, 41, 8557-8566. [CrossRef]

4. De Vleeschouwer, F.; Le Roux, G.; Shotyk, W. Peat as an archive of atmospheric pollution and environmental change : A case study of lead in Europe. PAGES Mag. 2010, 18, 20-22. [CrossRef]

5. Shotyk, W.; Weiss, D.; Appleby, P.G.; Cheburkin, A.K.; Frei, R.; Gloor, M.; Kramers, J.D.; Reese, S.; Van Der Knaap, W.O. History of atmospheric lead deposition since $12,370{ }^{14} \mathrm{C}$ yr BP recorded in a peat bog profile, Jura Mountains, Switzerland. Science 1998, 281, 1635-1640. [CrossRef] [PubMed]

6. Komárek, M.; Ettler, V.; Chrastny, V.; Mihaljevic, M. Lead isotopes in environmental sciences: A review. Environ. Int. 2008, 34, 562-577. [CrossRef] [PubMed]

7. Nriagu, J.O. Tales Told in Lead. Science 1998, 281, 1622-1623. [CrossRef]

8. Doe, B.R. Lead Isotopes; Springer: New York, NY, USA, 1970; p. 137.

9. Allan, M.; Fagel, N.; Van Rampelbergh, M.; Baldini, J.; Riotte, J.; Cheng, H.; Edwards, R.L.; Gillikin, D.; Quinif, Y.; Verheyden, S. Lead concentrations and isotope ratios in speleothems as proxies for atmospheric metal pollution since the industrial revolution. Chem. Geol. 2015, 401, 140-150. [CrossRef]

10. Klaminder, J.; Renberg, I.; Bindler, R. Isotopic trends and background fluxes of atmospheric lead in northern Europe: Analysis of three ombrotrophic bogs from Sweden. Glob. Biogeochem. Cycles 2003, 17, 1019-1028. [CrossRef]

11. Ferrat, M.; Weiss, D.J.; Dong, S.; Large, D.J.; Spiro, B.; Sun, Y.; Gallagher, K. Lead atmospheric deposition rates and isotopic trends in Asian dust during the last $9.5 \mathrm{kyr}$ recorded in an ombrotrophic peat bog on the eastern Qinghai-Tibetan Plateau. Geochim. Cosmochim. Acta 2012, 82, 4-22. [CrossRef]

12. Dunlap, C.E.; Steinnes, E.; Flegal, A.R. A synthesis of lead isotopes in two millennia of European air. Earth Planet. Sci. Lett. 1999, 167, 81-88. [CrossRef] 
13. Kylander, M.E.; Weiss, D.J.; Martinez Cortizas, A.; Spiro, B.; Garcia-Sanchez, R.; Coles, B.J. Refining the preindustrial atmospheric $\mathrm{Pb}$ isotope evolution curve in Europe using an 8000 year old peat core from NW Spain. Earth Planet. Sci. Lett. 2005, 240, 467-485. [CrossRef]

14. Hong, S.; Candelone, J.P.; Patterson, C.C.; Bouton, C.F. Greenland Ice Evidence of Hemispheric Lead Pollution Two Millennia Ago by Greek and Roman Civilization. Science 1994, 265, 1841-1843. [CrossRef] [PubMed]

15. Fagel, N.; Lechenault, M.; Fontaine, F.; Pleuger, E.; Otten, J.; Allan, M.; Ghilardi, M.; Mattielli, N.; GoiraN, J.P. Record of human activities in the $\mathrm{Pb}$ isotopes signatures of coastal sediments from the Roman archaeological site of Cala Francese, Cape Corsica (France). J. Archaeol. Sci. 2017, 12, 770-781. [CrossRef]

16. Renberg, I.; Brannvall, M.L.; Bindler, R.; Emteryd, O. Atmospheric lead pollution history during four millennia (2000 BC to 2000 AD) in Sweden. Ambio 2000, 29, 150-156. [CrossRef]

17. Martínez, C.A.; López-Merino, L.; Bindler, R.; Mighall, T.; Kylander, M. Early atmospheric metal pollution provides evidence for Chalcolithic/Bronze Age mining and metallurgy in Southwestern Europe. Sci. Total Environ. 2016, 545-546, 398-406. [CrossRef] [PubMed]

18. Settle, D.; Patterson, C.C. Lead in Albacore: Guide to lead pollution in Americans. Science 1980, 207, 1167-1176. [CrossRef] [PubMed]

19. Brännvall, M.L.; Bindler, R.; Emteryd, O.; Renberg, I. Four thousand years of atmospheric lead pollution in northern Europe: A summary from Swedish lake sediments. J. Paleolimnol. 2001, 25, 421-435. [CrossRef]

20. Mighall, T.M.; Timberlake, S.; Foster, I.D.L.; Krupp, E.; Singh, S. Ancient copper and lead pollution records from a raised bog complex in Central Wales. J. Archaeol. Sci. 2009, 36, 1504-1515. [CrossRef]

21. Nriagu, J.O. Occupational exposure to lead in ancient times. Sci. Total Environ. 1983, 31, 105-116. [CrossRef]

22. Véron, A.; Goiran, J.P.; Morhange, C.; Marriner, N.; Empereur, J.Y. Pollutant lead reveals the pre-Hellenistic occupation and ancient growth of Alexandria, Egypt. Geophys. Res. Lett. 2006, 33, 1-4. [CrossRef]

23. Damman, A.W.H. Hydrology, development, and biochemistry of ombrogenous peat bogs with special reference to nutrient relocation in a western Newfoundland bog. Can. J. Bot. 1986, 64, 384-394. [CrossRef]

24. Shotyk, W.; Cheburkin, K.; Appleby, P.G.; Fankhauser, A.; Kramers, J.D. Two thousand years of atmospheric arsenic, antimony, and lead deposition recorded in an ombrotrophic peat bog profile, Jura Mountains, Switzerland. Earth Planet. Sci. Lett. 1996, 145, E1-E7. [CrossRef]

25. Martinez-Cortizas, A.; Pontevedra-Pombal, X.; Novoa-Munoz, J.C.; Garcia-Rodeja, E. Four thousand years of atmospheric $\mathrm{Pb}, \mathrm{Cd}$ and $\mathrm{Zn}$ deposition recorded by the ombrotrophic peat bog of Penido Vello (Northwestern Spain). Water Air Soil Pollut. 1997, 100, 387-403. [CrossRef]

26. Farmer, J.G.; Anderson, P.; Cloy, J.M.; Graham, M.C.; MacKenzie, A.B.; Cook, G.T. Historical accumulation rates of mercury in four Scottish ombrotrophic peat bogs over the past 2000 years. Sci. Total Environ. 2009, 407, 5578-5588. [CrossRef] [PubMed]

27. Shotyk, W. The chronology of anthropogenic, atmospheric $\mathrm{Pb}$ deposition recorded by peat cores in three minerogenic peat deposits from Switzerland. Sci Total Environ. 2002, 292, 19-31. [CrossRef]

28. Shotyk, W.; Goodsite, M.E.; Roos-Barraclough, F.; Frei, R.; Heinemeier, J.; Asmund, G.; Lohse, C.; Hansen, T.S. Anthropogenic contributions to atmospheric $\mathrm{Hg}, \mathrm{Pb}$ and $\mathrm{As}$ accumulation recorded by peat cores from southern Greenland and Denmark dated using the 14C "bomb pulse curve". Geochim. Cosmochim. Acta 2003, $67,3991-4011$.

29. Vile, M.A.; Wieder, R.K.; Novak, M. Mobility of Pb in Sphagnum-derived peat. Biogeochemistry 1999, 45, 35-52. [CrossRef]

30. Weiss, D.; Shotyk, W.; Kramers, J.D.; Gloor, M. Sphagnum mosses as archives of recent and past atmospheric lead deposition in Switzerland. Atmos. Environ. 1999, 33, 3751-3763.

31. Rausch, N.; Ukonmaanaho, L.; Nieminen, T.; Krachler, M.; Shotyk, W. Porewater evidence of metal (Cu, Ni, $\mathrm{Co}, \mathrm{Zn}, \mathrm{Cd}$ ) mobilization in an acidic, ombrotrophic bog impacted by a smelter, Harjavalta, Finland and comparison with reference sites. Environ. Sci. Technol. 2005, 39, 8207-8213. [CrossRef] [PubMed]

32. Rausch, N.; Nieminen, T.; Ukonmaanaho, L.; Le Roux, G.; Krachler, M.; Cheburkin, A.K.; Bonani, G.; Shotyk, W. Comparison of atmospheric deposition of copper, nickel, cobalt, zinc and cadmium recorded by Finnish peat cores with monitoring data and emission records. Environ. Sci. Technol. 2005, 39, 5989-5998. [CrossRef] [PubMed]

33. Damman, A.W.H. Distribution and movement of elements in ombrotrophic peat bogs. Oikos 1978, 30, 480-495. [CrossRef] 
34. Shotyk, W.; Kempter, H.; Krachler, M.; Zaccone, C. Stable $\left({ }^{206} \mathrm{~Pb},{ }^{207} \mathrm{~Pb},{ }^{208} \mathrm{~Pb}\right)$ and radioactive $\left({ }^{210} \mathrm{~Pb}\right)$ lead isotopes in 1 year of growth of Sphagnum moss from four ombrotrophic bogs in southern Germany: Geochemical significance and environmental implications. Geochim. Cosmochim. Acta 2015, 163, 101-125. [CrossRef]

35. Shotyk, W.; Weiss, D.; Kramers, J.D.; Frei, R.; Cheburkin, A.K.; Gloor, M.; Reese, S. Geochemistry of the peat bog at Etang de la Gruère, Jura Mountains, Switzerland, and its record of atmospheric $\mathrm{Pb}$ and lithogenic trace metals (Sc, Ti, Y, Zr, and REE) since $12,370{ }^{14} \mathrm{C}$ yr BP. Geochim. Cosmochim. Acta 2001, 65, 2337-2360. [CrossRef]

36. Weiss, D.; Shotyk, W.; Boyle, A.E.; Kramers, D.J.; Appleby, P.G.; Cheburkin, A.K. Comparative study of the temporal evolution of atmospheric lead deposition in Scotland and eastern Canada using blanket peat bog. Sci. Total Environ. 2002, 292, 7-18. [CrossRef]

37. Farmer, J.G.; Eades, L.J.; Atkins, H.; Chamberlain, D.F. Historical trends in the lead isotopic composition of archival Sphagnum mosses from Scotland (1838-2000). Environ. Sci. Technol. 2002, 36, 152-157. [CrossRef] [PubMed]

38. Le Roux, G.; Aubert, D.; Stille, P.; Krachler, M.; Kober, B.; Cheburkin, A.; Bonani, G.; Shotyk, W. Recent atmospheric $\mathrm{Pb}$ deposition at a rural site in southern Germany assessed using a peat core and snowpack, and comparison with other archives. Atmos. Environ. 2005, 39, 6790-6801. [CrossRef]

39. Olid, C.; Garcia-Orellana, J.; Martínez-Cortizas, A.; Masqué, P.; Peiteado-Varela, E.; Sanchez-Cabeza, J.A. Multiple site study of recent atmospheric metal $(\mathrm{Pb}, \mathrm{Zn}$ and $\mathrm{Cu}$ ) deposition in the NW Iberian Peninsula using peat cores. Sci. Total Environ. 2010, 408, 5540-5549. [CrossRef] [PubMed]

40. Remy, H. Monographie archéologique Commune de Vielsalm. In Glain et Salm Haute Ardenne-Vielsalm; Haute Ardenne: Vielsalm, Belgique, 1981; pp. 44-69. (In French)

41. Damblon, F. Les dépôts tourbeux et l'histoire de la végétation sur le plateau des Hautes Fagnes (Belgique). Ann. Soc. Géol. Belg. 1994, 117, 259-276.

42. De l'or en Ardenne; L. Grailet: Tongres, Belgique, 1998; 112p. (In French)

43. De Vleeschouwer, F.; Gerard, L.; Goormaghtigh, C.; Mattielli, N.; Le Roux, G.; Fagel, N. Atmospheric lead and heavy metal pollution records from a Belgian peat bog spanning the last two millennia: Human impact on a regional to global scale. Sci. Total Environ. 2007, 377, 282-295. [CrossRef] [PubMed]

44. Renson, V.; Fagel, N.; Mattielli, N.; Nekrassoff, S.; Streel, M.; De Vleeschouwer, F. Roman road pollution assessed by elemental and lead isotope geochemistry in East Belgium. Appl. Geochem. 2008, 23, 3253-3266. [CrossRef]

45. Streel, M.; Renson, V.; Fagel, N.; Nekrassoff, S.; De Vleeschouwer, F. La route pavée au travers des tourbières de la fagne des Wez (via Mansuerisca?) est-elle romaine ou mérovingienne? La vérité est-elle ...à mi-chemin? Hautes Fagnes 2005, 259, 20-25. (In French)

46. Cauuet, B. Les mines d'or antiques d'Europe hors péninsule lbérique. État des connaissances et travaux récents, Mines et métallurgies dans l'Antiquité. Etat des recherches-Dossier thématique. Pallas 2005, 67, 241-291. (In French)

47. Renson, V. Apport de la géochimie élémentaire et des isotopes du plomb à l'étude d'un site d'intérêt archéologique situé dans une tourbière des Hautes Fagnes. Master's Thesis, University of Liège, Wallonia, Belgium, July 2005. (In French)

48. Streel, M.; Renson, V.; De Vleeschouwer, F. Palynological and geochemical data in peat sediments alongside an old (Roman or Merovingian) paved road in the Hautes-Fagnes. In Recent Advances in Palynology; Carnets de Géologie: Brest, France, 2007; pp. 53-58.

49. Kempter, H. Der Verlauf des anthropogenen elementeintrags in Regenwassermoore des westlichen Mitteleuropas während des jüngeren Holozäns. Paläoklimaforschung 1996, 26, 309. (In German)

50. Gérard, L. Suivi des apports atmosphériques en plomb au cours de l'Holocène. Bachelor's Thesis, University of Liège, Wallonia, Belgium, July 2004. (In French)

51. Goormaghtigh, C. Suivi des apports atmosphériques en métaux lourds durant la période Subatlantique (depuis 850 ans), dans un milieu continental pollué: enregistrement de deux tourboères des Hautes Fagnes (Belgique). Bachelor's Thesis, University of Liège, Wallonia, Belgium, July 2005. (In French)

52. Sonk, J.E.; Hoogewerff, J.A.; Van, D.L.; Sieger, R.; Vangronsveld, J. A chemical and mineralogical reconstruction of $\mathrm{Zn}$-smelter emissions in the Kempen region (Belgium), based on organic pool sediment cores. Sci. Total Environ. 2002, 292, 101-109. [CrossRef] 
53. Verniers, J.; Herbosch, A.; Vanguestaine, M.; Geukens, F.; Delcambre, B.; Pingot, J.L.; Belanger, I.; Hennebert, M.; Debacker, T.N.; Sintubin, M.; et al. Cambrian-Ordovician- Silurian lithostratigraphic units (Belgium). Geolog. Belg. 2001, 4, 5-38.

54. Bourgignon, P. Associations mine'ralogiques des limons et argiles des hautes-Fagnes. Ann. Soc. Geol. Belg. 1953, 77B, 39-59.

55. Wastiaux, C.; Schumacker, R. Topographie de surface et de subsurface des zones tourbeuses des réserves naturelles domaniales des Hautes-Fagnes. Convention C60 entre le Ministère de la Région Wallonne; Direction générale des Ressources naturelles et de l'Environnement, et l'Université de Lièg: Liège, Belgique, 2003. (In French)

56. Deru, X. Die Römer an Maas und Mosel; Mainz am Rhein, Verlag Philipp von Zabern: Darmstadt, Germany, 2010; p. 136. (In German)

57. Belokopytov, I.E.; Veresnevich, V.V. Giktorf's peat borers. Torf. Prom. 1955, 8, 9-10.

58. Givelet, N.; Le Roux, G.; Cheburkin, A.; Chen, B.; Frank, J.; Goodsite, M.; Kempter, H.; Krachler, M.; Noernberg, T.; Rausch, N.; et al. Suggested protocol for collecting, handling and preparing peat cores and peat samples for physical, chemical, mineralogical and isotopic analyses. J. Environ. Monit. 2004, 6, 481-492. [CrossRef] [PubMed]

59. Allan, M.; Loader, N.J.; Gillikin, D.P.; Lenoir, G.; Verheyden, S.; Crucifix, M.; Piotrowska, N.; Sikorski, J.; Fagel, N. Reconstruction of mid-late Holocene climate in NW Europe from high-resolution peat cellulose stable isotope records. J. Quat. Sci. 2018. submitted for publication.

60. Allan, M.; Le Roux, G.; Piotrowska, N.; Beghin, J.; Javaux, E.; Court- Picon, M.; Mattielli, N.; Verheyden, S.; Fagel, N. Mid and late Holocene dust deposition in western Europe: The Misten peat bog (Hautes Fagnes-Belgium). Clim. Past 2013, 9, 2889-2928. [CrossRef]

61. Fagel, N.; Allan, M.; Le Roux, G.; Mattielli, N.; Piotrowska, N.; Sikorski, J. Deciphering human-climate interactions in an ombrotrophic peat record: $\mathrm{REE}, \mathrm{Nd}$ and $\mathrm{Pb}$ isotope signatures of dust supplies over the last 2500 years (Misten bog, Belgium). Geochim. Cosmochim. Acta 2014, 135, 288-306. [CrossRef]

62. De Vleeschouwer, F.; van Vliët-Lanoé, B.; Fagel, N.; Richter, T.; Boës, X. Development and application of high-resolution petrography on resin-impregnated Holocene peat columns to detect and analyse tephras, cryptotephras, and other materials. Quat. Int. 2008, 178, 54-67. [CrossRef]

63. Boës, X.; Piotrowska, N.; Fagel, N. Highresolution diatom/clay record in Lake Baikal from grey scale, and magnetic susceptibility over Holocene and Termination I. Glob. Planet. Chang. 2005, 46, 299-313. [CrossRef]

64. Thirlwall, M.F. Multicollector ICP-MS analysis of $\mathrm{Pb}$ isotopes using a ${ }^{207} \mathrm{~Pb}-{ }^{204} \mathrm{~Pb}$ double spike demonstrates up to $400 \mathrm{ppm} / \mathrm{amu}$ systematic errors in Tlnormalization. Chem. Geol. 2002, 184, 255-279. [CrossRef]

65. Kempter, H.; Gorres, M.; Frenzel, B. Ti and $\mathrm{Pb}$ concentrations in rainwater-fed bogs in Europe as indicators of past anthropogenic activities. Water Air Soil Pollut. 1997, 100, 367-377. [CrossRef]

66. Shotyk, W.; Blaser, P.; Grünig, A.; Cheburkin, A.K. A new approach for quantifying cumulative, anthropogenic, atmospheric lead deposition using peat cores from bogs: $\mathrm{Pb}$ in eight Swiss peat bog profiles. Sci. Total Environ. 2000, 249, 281-295. [CrossRef]

67. Martinez, C.A.; Peiteado, V.E.; Bindler, R.; Biester, H.; Cheburkin, A. Reconstructing historical Pb and $\mathrm{Hg}$ pollution in NW Spain using multiple cores from the Chao de Lamoso bog (Xistral Mountains). Geochim. Cosmochim. Acta 2012, 82, 68-78. [CrossRef]

68. Bindler, R.; Klarqvist, M.; Klaminder, J.; Förster, J. Does within-bog spatial variability of mercury and lead constrain reconstructions of absolute deposition rates from single peat records? The example of Store Moss, Sweden. Glob. Biogeochem. Cycles 2004, 18, GB3020. [CrossRef]

69. Allan, M.; Le Roux, G.; Sonke, J.E.; De Vleeschouwer, F.; Piotrowska, N.; Sikorski, J.; Streel, M.; Fagel, N. Historical record of atmospheric mercury deposition in Western Europe: The Misten peat bog (Hautes Fagnes-Belgium). Sci. Total Environ. 2013, 442, 290-301. [CrossRef] [PubMed]

70. Brannvall, M.L.; Bindler, R.; Emteryd, O.; Nilsson, M.; Renberg, I. Stable lead isotopes and concentration records of atmospheric lead pollution in peat and lake sediments in Sweden. Water Air Soil Pollut. 1997, 100, 243-252. [CrossRef]

71. Cauet, S.W.D.; Herbosh, A. Genetic study of Belgian lead zinc mineralizations in carbonate environments through lead isotope geochemistry. Bull. BRGM 1982, 3, $29-41$.

72. Dejonghe, L. Zinc-lead deposits of Belgium. Ore Geol. Rev. 1998, 12, 329-354. [CrossRef] 
73. Durali-Mueller, S.; Brey, G.P.; Wigg-Wolf, D.; Lahaye, Y. Roman lead mining in Germany: Its origin and development through time deduced from lead isotope provenance studies. J. Archaeol. Sci. 2007, 34, 1555-1567. [CrossRef]

74. Bollhöfer, A.; Rosman, K.J.R. Lead isotopic ratios in European atmospheric aerosols. Phys. Chem. Earth. Part B Hydrol. Oceans Atmos. 2001, 26, 835-838. [CrossRef]

75. Millot, R.; Allègre, C.-J.; Gaillardet, J.; Roy, S. Lead isotopic systematics of major river sediments: A new estimate of the $\mathrm{Pb}$ isotopic composition of the Upper Continental Crust. Chem. Geol. 2004, 203, 75-90. [CrossRef]

76. Cloy, J.M.; Farmer, J.G.; Graham, M.C.; MacKenzie, A.B.; Cook, G.T. Historical records of atmospheric Pb deposition in four Scottish ombrotrophic peat bogs: An isotopic comparison with other records from western Europe and Greenland, Global Biogeochem. Cycles 2008, 22, GB2016. [CrossRef]

77. Meharg, A.A.; Edwards, K.J.; Schofield, J.E.; Raab, A.; Feldmann, J.; Moran, A.; Bryant, C.L.; Thornton, B.; Dawson, J.J.C. First comprehensive peat depositional records for tin, lead and copper associated with the antiquity of Europe's largest cassiterite deposits. J. Archaeol. Sci. 2012, 39, 717-727. [CrossRef]

78. Mariet, A.L.; Monna, F.; Gimbert, F.; Bégeot, C.; Cloquet, C.; Belle, S.; Millet, L.; Rius, D.; Water-Simonnet, A.V. Tracking past mining activity using trace metals, lead isotopes and compositional data analysis of a sediment core from Longemer Lake, Vosges Mountains, France. J. Paleolimnol. 2018, 1-14. [CrossRef]

79. Bindler, R.; Renberg, I.; Rydberg, J.; Andrén, T. Widespread waterborne pollution in central Swedish lakes and the Baltic Sea from pre-industrial mining and metallurgy. Environ. Pollut. 2009, 157, 2132-2141. [CrossRef] [PubMed]

80. Brännvall, M.-L.; Bindler, R.; Renberg, I.; Emteryd, O.; Bartnicki, J.; Billström, K. The medieval metal industry was the cradle of modern large-scale atmospheric lead pollution in northern Europe. Environ. Sci. Technol. 1999, 33, 4391-4395.

81. More, A.F.; Spauling, N.E.; Bohleber, P.; Handley, M.J.; Hoffman, H.; Korotkikh, E.V.; Kurbatov, A.V.; Loveluck, C.P.; Sneed, S.B.; McCormick, M.; Mayewski, P.A. Next-generation ice core technology reveals true minimum natural levels of lead $(\mathrm{Pb})$ in the atmosphere: Insights from the Black Death. GEO Health 2017, 1, 211-219. [CrossRef]

82. Osterberg, E.; Mayewski, P.; Kreutz, K.; Fisher, D.; Handley, M.; Sneed, S.; Zdanowicz, C.; Zheng, J.; Demuth, M.; Waskiewicz, M.; et al. Ice core record of rising lead pollution in the North Pacific atmosphere. Geophys. Res. Lett. 2008, 35, L05810. [CrossRef]

83. Shirahata, H.; Elias, R.W.; Patterson, C.C. Chronological variations in concentrations and isotopic compositions of anthropogenic atmospheric lead in sediments of a remote alpine pond. Geochim. Cosmochim. Acta 1980, 44, 149-162. [CrossRef]

84. Martinez, C.A.; López-Merino, L.; Bindler, R.; Mighall, T.; Kylander, M. Atmospheric Pb pollution in N Iberia during the late Iron Age/Roman times reconstructed using the high-resolution record of La Molina (Asturias, Spain). J. Paleolimnol. 2013, 50, 71-86. [CrossRef]

(C) 2018 by the authors. Licensee MDPI, Basel, Switzerland. This article is an open access article distributed under the terms and conditions of the Creative Commons Attribution (CC BY) license (http://creativecommons.org/licenses/by/4.0/). 